\title{
Coping with the Challenges of Abiotic Stress in Plants: New Dimensions in the Field Application of Nanoparticles
}

\author{
Vishnu D. Rajput ${ }^{1, *(\mathbb{D})}$, Tatiana Minkina ${ }^{1} \mathbb{D}$, Arpna Kumari ${ }^{2}$, Harish $^{3} \mathbb{D}$, Vipin Kumar Singh ${ }^{4}$, \\ Krishan K. Verma ${ }^{5}\left(\mathbb{D}\right.$, Saglara Mandzhieva ${ }^{1} \mathbb{D}$, Svetlana Sushkova ${ }^{1} \mathbb{D}$, Sudhakar Srivastava ${ }^{6}$ and \\ Chetan Keswani ${ }^{7}$
}

\section{check for} updates

Citation: Rajput, V.D.; Minkina, T.; Kumari, A.; Harish; Singh, V.K.; Verma, K.K.; Mandzhieva, S.; Sushkova, S.; Srivastava, S.; Keswani, C. Coping with the Challenges of Abiotic Stress in Plants: New Dimensions in the Field Application of Nanoparticles. Plants 2021, 10, 1221. https://doi.org/10.3390/plants 10061221

Academic Editor: Krzysztof Sitko

Received: 7 May 2021

Accepted: 11 June 2021

Published: 15 June 2021

Publisher's Note: MDPI stays neutral with regard to jurisdictional claims in published maps and institutional affiliations.

Copyright: (C) 2021 by the authors Licensee MDPI, Basel, Switzerland. This article is an open access article distributed under the terms and conditions of the Creative Commons Attribution (CC BY) license (https:/ / creativecommons.org/licenses/by/ $4.0 /)$.
1 Academy of Biology and Biotechnology, Southern Federal University, 344090 Rostov-on-Don, Russia; tminkina@mail.ru (T.M.); msaglara@mail.ru (S.M.); terra_rossa@mail.ru (S.S.)

2 Department of Botanical and Environmental Sciences, Guru Nanak Dev University, Amritsar 143005, India; arpnabot.rsh@gndu.ac.in

3 Plant Biotechnology Laboratory, Department of Botany, Mohan Lal Sukhadia University, Udaipur 313001, India; harish.botany1979@gmail.com

4 Centre of Advanced Studies in Botany, Institute of Science, Banaras Hindu University, Varanasi 221005, India vipinks85@gmail.com

5 Key Laboratory of Sugarcane Biotechnology and Genetic Improvement, Guangxi Academy of Agricultural Sciences/Sugarcane Research Center, Chinese Academy of Agricultural Sciences, Nanning 530007, China; drvermakishan@gmail.com

6 Plant Stress Biology Laboratory, Institute of Environment and Sustainable Development, Banaras, Banaras Hindu University, Varanasi 221005, India; sudhakar.iesd@bhu.ac.in

7 Department of Biochemistry, Institute of Science, Hindu University, Varanasi, 221005, India; chetan.keswani4@bhu.ac.in

* Correspondence: rajput.vishnu@gmail.com; Tel.: +7-918-589-00-93

Abstract: Abiotic stress in plants is a crucial issue worldwide, especially heavy-metal contaminants, salinity, and drought. These stresses may raise a lot of issues such as the generation of reactive oxygen species, membrane damage, loss of photosynthetic efficiency, etc. that could alter crop growth and developments by affecting biochemical, physiological, and molecular processes, causing a significant loss in productivity. To overcome the impact of these abiotic stressors, many strategies could be considered to support plant growth including the use of nanoparticles (NPs). However, the majority of studies have focused on understanding the toxicity of NPs on aquatic flora and fauna, and relatively less attention has been paid to the topic of the beneficial role of NPs in plants stress response, growth, and development. More scientific attention is required to understand the behavior of NPs on crops under these stress conditions. Therefore, the present work aims to comprehensively review the beneficial roles of NPs in plants under different abiotic stresses, especially heavy metals, salinity, and drought. This review provides deep insights about mechanisms of abiotic stress alleviation in plants under NP application.

Keywords: abiotic stresses; environmental contaminants; heavy metals; nanoparticles; soil

\section{Introduction}

In the current scenario, population explosion has emerged as one of the major challenges, especially for sustainable food production, in feeding the growing population [1]. The world population may reach up to 10.9 billion by 2100 and will lead to an increase in demand for food by nearly 50\%. To achieve the "Zero Hunger" goal, which is one of the goals of sustainable development of the UN to be achieved by 2030, there is an urgent need for revolutionizing conventional agricultural practices. Such changes can be achieved by employing eco-friendly and sustainable innovations [1-4].

Plants are unable to move physically from their location to prevent the consequences of environmental stress such as abiotic stresses. Among different abiotic stresses, heavy 
metal (HM) contamination, soil salinity, and drought stress are described to limit the crop productivity by multiple orders of magnitude [5-7]. These changes under abiotic stress trigger perturbations in the metabolism of plants, thereby facilitating reorganization of the metabolic network in order to keep the vital metabolic processes active [8-12].

Soil pollutants, especially $\mathrm{HMs}$ and metalloids such as $\mathrm{Cr}, \mathrm{Cd}, \mathrm{Ni}, \mathrm{Zn}, \mathrm{As}$, and $\mathrm{Hg}$, are identified as the most commonly detected contaminants $[13,14]$. The increased release of HMs in the terrestrial environment has been documented to severely affect the productivity of cultivated areas $[15,16]$. Furthermore, most of the metal contaminants eventually find their way into the terrestrial and aquatic environment, thereby directly or indirectly affecting human health and the associated ecosystems $[17,18]$. Additionally, there are ample chances of accumulation of HMs in plants exposed to contaminated areas [19].

Salinity and drought stresses are devastating stresses that are reported to limit the economic yield of several crops via inducing biochemical and physiological perturbations [20-22]. These stresses confine the plant productivity and growth due to osmotic stress, nutritional imbalance, and oxidative stress [23]. The salt stress results in the accumulation of sodium $\left(\mathrm{Na}^{+}\right)$and chloride $\left(\mathrm{Cl}^{-}\right)$ions in the cytosol, eventually causing considerable damage to the cell [24]. Drought stress is known to induce stomatal closure, to inhibit photosynthesis, to reduce the leaf area, to reduce the biomass and growth, to decrease the water potential, to increase the amount of osmolytes, and to induce the generation of reactive oxygen species (ROS) [25]. Abiotic stress triggers perturbation in the metabolism of plants, thereby facilitating reorganization of the metabolic networks in order to keep the vital processes active [8-12]. Thus, the onset of abiotic environmental stressors because of immobile nature of plants eventually leads to reduced crop productivity.

Numerous stress management strategies have been developed by researchers in recent decades. Among them, nanotechnology is one of the emerging strategies that has been anticipated to improve crop productivity [2,3]. Nevertheless, most of the research focusing on nanoparticles (NPs) currently is concentrated on their toxicity [4,26-29]. Relatively fewer publications are available regarding the role of NPs in crop protection, especially under various abiotic stress conditions $[8,30,31]$.

Nanoparticles may be described as materials with diameters between 1 to $100 \mathrm{~nm}$ in at least one dimension [32]. Metal and metal-based NPs show various physiochemical features that are different from their native bulk compounds. The application of NPs has gained widespread popularity in agriculture and allied sectors including various other fields, i.e., the chemical, optical, biomedical, pharmaceutical, food, and textile industries $[33,34]$. Different NPs for field applications such as nano-agrochemicals have been used to increase agricultural productivity. Some of them include phosphorous NPs $\left(\mathrm{Ca}_{5}\left(\mathrm{PO}_{4}\right)_{3} \mathrm{OH}\right)$, calcium NPs $\left(\mathrm{CaCO}_{3}\right), \mathrm{Mg}$ NPs, $\mathrm{ZnO}$ NPs, $\mathrm{Fe}_{2} \mathrm{O}_{3} \mathrm{NPs}, \mathrm{TiO}_{2} \mathrm{NPs}, \mathrm{Ag} \mathrm{NPs}\left(\mathrm{AgNO}_{3}\right), \mathrm{Mn} \mathrm{NPs}$ $\left(\mathrm{MnSO}_{4}\right), \mathrm{Cu} \mathrm{NPs}(\mathrm{CuO}), \mathrm{Mo} \mathrm{NPs}, \mathrm{SiO}_{4}$ and $\mathrm{AlO}_{4} \mathrm{CNTs}$ (carbon nanotubes), and a complex of Chitosan with $\mathrm{Zn}$ or $\mathrm{Cu}[4,35]$.

Nanoparticles as soil-improving agents, nano-fertilizers, nano-pesticides, growth stimulators, and nano-sensors for controlling various agricultural factors in the farm [36] have been utilized for improving crop yield. It has gained popular acceptance for its potential application in the smart and controlled delivery of pesticides and herbicides and in the sustained-release of fertilizer formulations. Additionally, the contribution of NPs in the alleviation of abiotic stress-induced toxicity in plants is of immense agricultural importance. The intervention of nanotechnology has demonstrated effectiveness not only in the removal of non-degradable metals, but also in the detoxification of slowly degrading contaminants [37]. The past decades have substantially received tremendous contribution about NPs improving plant growth and soil characteristics, particularly in the management of marginal soils affected by HM contamination [38,39]. In a recent study, the contents of chlorophyll ( $a$ and $b$ ) and carotenoids were noticeably enhanced by magnetic NP treatment to Hordeum vulgare, apart from the positive impacts on the genes of photosystems [40]. Likewise, the negative impacts of drought and salinity stress have also been mitigated by the use of NPs [41,42]. 
In order to obtain in-depth knowledge on field applications of NPs, the present review aimed to discuss the challenges of different abiotic stresses causing substantial changes in crops at the morphological, anatomical, biochemical, and physiological levels and the possible roles and mechanisms of NPs for mitigating the negative consequences of abiotic stresses to improve the agricultural productivity.

\section{Alleviation of Heavy Metal Toxicity in Plants Using Nanoparticles}

Excessive release of HMs in the environment by an exponential rise in anthropogenic activities and industrial processing is of great concern $[43,44]$. The risks of HM contamination in cultivated fields and aquatic environments due to the indiscriminate addition of various agro-fertilizers are of considerable concern $[45,46]$. The abundance of HMs in a given environmental matrix beyond certain limits exerts toxicity because of accumulation and genotoxic, carcinogenic, and mutagenic behaviors [46-49].

The HMs and metalloids associated with the environmental and human health concerns include $\mathrm{Cu}, \mathrm{Zn}, \mathrm{Cd}, \mathrm{Cr}, \mathrm{Pb}, \mathrm{As}$, and $\mathrm{Hg}$ [50,51]. Therefore, it is imperative to develop innovative and economical technologies for the successful elimination of HMs from contaminated sites. However, the characteristic toxicity at low concentrations, slow removal using conventional approaches, and non-biodegradable attributes of HMs [49,52-54] are the important factors imposing restrictions in successful detoxification from contaminated sites. The fabrication of effective and eco-friendly NPs for successful employment in managing widespread contamination of hazardous HMs has received much popularity [55]. Among the different metal and non-metal-based NPs, generally, those with an environmentally friendly nature, cost-effectiveness, and ease of availability are preferred for application in environmental clean-up programs as well as in the alleviation of toxicity [56].

The contribution of myriads of NPs in overcoming the challenges of HM-induced toxicity has been presented by various researchers worldwide (Table 1). In general, it has been observed that NPs minimize the uptake of HMs by modifying the expression of genes responsible for metal uptake and by reducing HM bioaccumulation. Furthermore, NP treatment improves the physiological and biochemical parameters of the plants such as enhancing the synthesis of defense enzymes (SOD, POX, CAT, APX, etc.); augmenting nutrient uptake; decreasing the loss of electrolytes; improving pigments and soluble proteins; reducing peroxidation; and causing rise in the levels of proline, glutathione, and phyto-chelatins. These attributes are primarily responsible for the overall increase in the tolerance of the crops and may vary slightly according to different plant species.

Plants employ two strategies to mitigate toxic effects by HMs and to protect their organs, i.e., restricting the uptake and accumulation of HMs with tolerance mechanism applications. The plants accumulate HMs within the plant cell; therefore, remediation is possible by such species. The plants restrict this uptake; thus, farming of such crops is possible without any significant accumulation of HMs in the plant biomass. Noman et al. [57] suggested the contribution of bacterially synthesized $\mathrm{Cu}$ NPs in counteracting $\mathrm{Cr}$-induced toxicity in Triticum aestivum L. The $\mathrm{Cu}$ NPs amended in the soil at the rate of 25 and $50 \mathrm{mg} / \mathrm{kg}$ were shown to improve the growth, biomass, and antioxidant pool. The NP treatment was found effective in lowering the synthesis of ROS as well as $\mathrm{Cr}$ transport into the plant under $\mathrm{Cr}$ stress by substantial soil immobilization. Similar reports on microbially fabricated $\mathrm{Cu}$-based NPs facilitating the alleviation of Cr-induced toxicity and reduced translocation in plant parts conferred by metal immobilization with the resultant improvement in nutrient uptake and biomass were also presented [58]. The mitigation of rising challenges linked with $\mathrm{Cd}$ phytotoxicity in Oryza sativa L. was recently demonstrated using $\mathrm{Fe}_{2} \mathrm{O}_{3}$ NPs [59]. The addition of NPs improved the level/activity of detoxifying enzymes, photosynthetic potential, and nutrient uptake attributes. Noticeably, the application of NPs helped in reducing the formation of ROS, lowered the expression of genes supporting the transport of $\mathrm{Cd}$, and restricted mobilization in leaves. For example, the application of $\mathrm{Fe}_{2} \mathrm{O}_{3}$ NPs reduced Cd transport by $70 \%$ in T. aestioum L. [60]. 
Researchers have suggested the application of biologically synthesized NPs for the management of HM-contaminated agricultural lands and the improvement of plant growth and development [61]. The foliar application of $\mathrm{TiO}_{2}$ in counteracting the effects of $\mathrm{Cd}$ in Zea mays as opposed to root supplementation was observed [62]. Treatment with different sizes of Si NPs led to a reduction in growth inhibition of Glycine max caused by Hg [63]. Moreover, Si NP-assisted improvement in chlorophyll content as declined by Hg exposure was also observed. The amendment of Si NPs led to a lowered accumulation of $\mathrm{Hg}$ in roots and shoots as confirmed by $\mathrm{X}$-ray fluorescence and was proposed as an innovative methodology to passivate volatile contaminants such as $\mathrm{Hg}$.

Recently, the investigation on the effectiveness of Au NPs to alleviate the hazardous effects induced by $\mathrm{Cd}$ in O. sativa L. under hydroponic conditions was presented [64]. The treatment of $O$. sativa L. plantations with Au NPs caused considerable reductions in the level of $\mathrm{Cd}$ in roots and leaves by 33 and $46.2 \%$, respectively. Media supplementation with the NPs in question caused an improvement in antioxidant defense enzymes facilitating the diminution of oxidative stress in O. sativa L. challenged by $\mathrm{Cd}$. The application of $\mathrm{Au}$ NPs also helped in restricting the expression of genes closely associated with metal transport across the cells [64]. Similar investigations on the role of different NPs such as Si NPs [65], biologically synthesized Cu NPs [58], ZnO NPs [66], Ti NPs [67], Se NPs [68], and $\mathrm{Fe}_{2} \mathrm{O}_{3}$ NPs [60] in metal detoxification in different plant parts were also reported.

Table 1. Applications of NPs in the mitigation of HMs stress by altering the morphophysiological responses of plants.

\begin{tabular}{|c|c|c|c|c|}
\hline Nanoparticles & Plants & $\begin{array}{l}\text { Germination and } \\
\text { Morphological } \\
\text { Responses }\end{array}$ & Physiological Responses & References \\
\hline Si $(10 \mu \mathrm{M})$ & Pisum sativum L. & $\begin{array}{l}\text { Presence of Si NPs } \\
\text { improved the growth } \\
\text { in presence of } \mathrm{Cr}\end{array}$ & $\begin{array}{l}\text { Si NPs minimized the Cr storage, } \\
\text { enhanced the synthesis of } \\
\text { defense enzymes and } \\
\text { augmented nutrient uptake }\end{array}$ & [69] \\
\hline $\mathrm{ZnO}(25 \mathrm{mg} / \mathrm{L})$ & Leucaena leucocephala & $\begin{array}{l}\text { Application of NPs } \\
\text { induced seedling } \\
\text { growth }\end{array}$ & $\begin{array}{l}\text { ZnO NPs amendment improved } \\
\text { pigments and soluble proteins, } \\
\text { reduced peroxidation; there was } \\
\text { rise in the antioxidant defense } \\
\text { enzymes }\end{array}$ & [70] \\
\hline $\mathrm{Fe}_{3} \mathrm{O}_{4}$ & Triticum aestivum L. & $\begin{array}{l}\mathrm{Fe}_{3} \mathrm{O}_{4} \mathrm{NP} \text { treatment } \\
\text { minimized the } \\
\text { inhibitory action of } \\
\mathrm{HMs}\end{array}$ & $\begin{array}{l}\mathrm{Fe}_{3} \mathrm{O}_{4} \mathrm{NPs} \text { supplementation } \\
\text { improved the level of superoxide } \\
\text { dismutase and peroxidase }\end{array}$ & [71] \\
\hline Si $(19,48$, and 202 nm) & Oryza sativa L. & $\begin{array}{l}\text { Si NPs enhanced the } \\
\text { number of cultured } \\
\text { cells and decreased } \\
\text { proportionally with the } \\
\text { rise in NP size; the } \\
\text { treatment maintained } \\
\text { the cellular integrity in } \\
\text { the presence of metals }\end{array}$ & $\begin{array}{l}\text { Si NPs amendment caused } \\
\text { altered expression of genes } \\
\text { responsible for reduced metal } \\
\text { uptake }\end{array}$ & [72] \\
\hline $\begin{array}{c}\mathrm{ZnO}(0,50,75, \text { and } \\
100 \mathrm{mg} / \mathrm{L})\end{array}$ & Zea mays L. & $\begin{array}{l}\text { Treatment caused rise } \\
\text { in plant length, leaf } \\
\text { number, and biomass }\end{array}$ & $\begin{array}{l}\mathrm{ZnO} \text { NPs application enhanced } \\
\text { chlorophyll content, gas } \\
\text { exchange characteristics, and } \\
\text { antioxidant enzymes; addition } \\
\text { led to reduced content of } \mathrm{Cd} \text { in } \\
\text { root and shoot }\end{array}$ & [73] \\
\hline $\begin{array}{c}\mathrm{ZnO}(0,25,50,75 \text {, and } \\
100 \mathrm{mg} / \mathrm{L}) \text { and Fe NPs } \\
(0,5,10,15, \text { and } \\
20 \mathrm{mg} / \mathrm{L})\end{array}$ & T. aestivum L. & $\begin{array}{l}\text { Treatment induced } \\
\text { plant growth, dry } \\
\text { weight, and grains } \\
\text { under Cd stress }\end{array}$ & $\begin{array}{l}\text { Addition of NPs decreased the } \\
\text { loss of electrolyte and activity of } \\
\text { superoxide dismutase and } \\
\text { peroxidase along with } \\
\text { diminished Cd accumulation }\end{array}$ & {$[74]$} \\
\hline
\end{tabular}


Table 1. Cont.

\begin{tabular}{|c|c|c|c|c|}
\hline Nanoparticles & Plants & $\begin{array}{l}\text { Germination and } \\
\text { Morphological } \\
\text { Responses }\end{array}$ & Physiological Responses & References \\
\hline $\mathrm{Si}$ & Glycine max L. & $\begin{array}{l}\text { Si NPs minimized the } \\
\text { growth inhibitory } \\
\text { action of } \mathrm{Hg}\end{array}$ & $\begin{array}{l}\text { Incorporation of } \mathrm{Si} \mathrm{NPs} \\
\text { improved the chlorophyll } \\
\text { content and reduced the } \mathrm{Hg} \\
\text { content in root and shoot }\end{array}$ & [63] \\
\hline Mel-Au $(200 \mu \mathrm{M})$ & O. sativa $\mathrm{L}$. & - & $\begin{array}{l}\text { Application of Mel-Au NPs } \\
\text { caused reduction of Cd level in } \\
\text { root and shoot, improved } \\
\text { chlorophyll content and raised } \\
\text { the activity of antioxidant } \\
\text { enzymes }\end{array}$ & {$[64]$} \\
\hline $\mathrm{Fe}(25$ and $50 \mathrm{mg} / \mathrm{L})$ & O. sativa $\mathrm{L}$. & $\begin{array}{l}\text { Treatment of Fe NPs } \\
\text { improved plant length } \\
\text { and dry weight }\end{array}$ & $\begin{array}{l}\text { Fe NPs application caused rise in } \\
\text { the level of proline, glutathione } \\
\text { and phyto-chelatins; Fe NPs } \\
\text { addition led to improved } \\
\text { defense enzymes and glyoxalase } \\
\text { machinery }\end{array}$ & [19] \\
\hline $\mathrm{ZnO}(10-100 \mathrm{mg} / \mathrm{L})$ & O. sativa $\mathrm{L}$. & $\begin{array}{l}\text { Amendment of } \mathrm{ZnO} \\
\text { increased the growth of } \\
\text { seedlings }\end{array}$ & $\begin{array}{l}\text { Treatment facilitated reduced } \\
\text { accumulation of arsenic in root } \\
\text { and shoot together with rise in } \\
\text { phytochelatin level }\end{array}$ & {$[75]$} \\
\hline $\begin{array}{c}\mathrm{Cu}(25,50, \text { and } 100 \mathrm{mg} \\
\left.\mathrm{kg}^{-1} \text { of soil }\right)\end{array}$ & T. aestivum $\mathrm{L}$. & $\begin{array}{l}\text { Rise in plant height and } \\
\text { shoot dry weight }\end{array}$ & $\begin{array}{l}\text { Increase in } \mathrm{N} \text { and } \mathrm{P} \text { content; } \\
\text { reduced } \mathrm{Cd} \text { transport, rise in the } \\
\text { level of vital ions and } \\
\text { antioxidant pool }\end{array}$ & [58] \\
\hline $\begin{array}{l}\mathrm{Cu}(0,25,50, \text { and } 100 \\
\left.\mathrm{mg} \mathrm{kg}^{-1} \text { of soil }\right)\end{array}$ & T. aestivum L. & $\begin{array}{l}\text { Improved biomass and } \\
\text { growth }\end{array}$ & $\begin{array}{l}\text { Reduced Cr availability; increase } \\
\text { in nutrient uptake; rise in } \\
\text { antioxidant content }\end{array}$ & [57] \\
\hline $\begin{array}{c}\mathrm{Fe}_{2} \mathrm{O}_{3}(0,25,50, \text { and } \\
\left.100 \mathrm{mg} \mathrm{kg}^{-1} \text { soil }\right)\end{array}$ & O. sativa $\mathrm{L}$. & $\begin{array}{l}\text { Improved fresh and dry } \\
\text { biomass; increased } \\
\text { height }\end{array}$ & $\begin{array}{l}\text { Augmented detoxifying } \\
\text { enzymes, photosynthetic } \\
\text { potential, and nutrient uptake } \\
\text { attributes; reduced formation of } \\
\text { ROS, lowered expression of } \\
\text { genes supporting the transport } \\
\text { of Cd; restricted Cd mobilization } \\
\text { in upper plant parts }\end{array}$ & [59] \\
\hline $\begin{array}{l}\mathrm{Fe}_{2} \mathrm{O}_{3}(25,50, \text { and } 100 \\
\left.\mathrm{mg} \mathrm{kg}^{-1} \text { soil }\right)\end{array}$ & T. aestivum L. & $\begin{array}{l}\text { Rise in plant fresh and } \\
\text { dry biomass; increase } \\
\text { in plant length }\end{array}$ & $\begin{array}{l}\text { Reduced Cd transport; enhanced } \\
\mathrm{N}, \mathrm{P} \text {, and K content; increased } \\
\text { antioxidants and pigment } \\
\text { content }\end{array}$ & {$[60]$} \\
\hline $\begin{array}{c}\mathrm{TiO}_{2}(0,100, \text { and } 250 \\
\mathrm{mg} / \mathrm{L} \text { soil })\end{array}$ & Z. mays & $\begin{array}{l}\text { Foliar application } \\
\text { improved shoot and } \\
\text { root dry weight }\end{array}$ & $\begin{array}{l}\text { Reduced accumulation of } \mathrm{Cd} \text {; } \\
\text { increased activities of } \\
\text { antioxidant enzymes }\end{array}$ & {$[61]$} \\
\hline $\mathrm{SiO}_{2}(30$ and $50 \mathrm{~nm})$ & G. $\max$ & $\begin{array}{l}\text { Improved seedling } \\
\text { fresh weight }\end{array}$ & $\begin{array}{l}\text { Improved chlorophyll content; } \\
\text { lowered accumulation of } \mathrm{Hg} \text { in } \\
\text { root }\end{array}$ & [63] \\
\hline $\begin{array}{c}\text { Si }(0,25,50, \text { and } 100 \\
\mathrm{mg} / \mathrm{kg} \text { soil })\end{array}$ & T. aestivum L. & Improved plant height & $\begin{array}{l}\text { Reduced level of Cd in root and } \\
\text { leaves by } 33 \text { and } 46.2 \% \text {, } \\
\text { respectively; improvement in } \\
\text { antioxidant defense enzyme; } \\
\text { restricted expression of genes } \\
\text { associated with metal transport } \\
\text { Improved chlorophyll; } \\
\text { photosynthesis; diminished Cd } \\
\text { content in tissues; }\end{array}$ & {$[64]$} \\
\hline
\end{tabular}


Table 1. Cont.

\begin{tabular}{|c|c|c|c|c|}
\hline Nanoparticles & Plants & $\begin{array}{l}\text { Germination and } \\
\text { Morphological } \\
\text { Responses }\end{array}$ & Physiological Responses & References \\
\hline $\begin{array}{c}\mathrm{ZnO}(0,50 \text {, and } 100 \mathrm{mg} \\
\left.\mathrm{L}^{-1}\right)\end{array}$ & G. $\max$ & $\begin{array}{l}\text { Improved root and } \\
\text { shoot growth }\end{array}$ & $\begin{array}{l}\text { Reduced arsenic concentration } \\
\text { in root and shoot; improved } \\
\text { photosynthesis, water loss, } \\
\text { photochemical yield; raised } \\
\text { antioxidative defense enzymes }\end{array}$ & [66] \\
\hline $\mathrm{Ti}(0.1$ to $0.25 \%)$ & Vigna radiata $L$. & $\begin{array}{l}\text { Augmented radicle } \\
\text { length and biomass }\end{array}$ & $\begin{array}{l}\text { Decline in the level of ROS and } \\
\text { lipid peroxidation; upregulation } \\
\text { of genes related with } \\
\text { antioxidative enzymes }\end{array}$ & [67] \\
\hline $\begin{array}{l}\text { Se and } \operatorname{Si~}(5,10 \text {, and } 20 \\
\left.\mathrm{mg} \mathrm{L}^{-1}\right)\end{array}$ & O. sativa L. & - & $\begin{array}{l}\text { Lowered accrual of } \mathrm{Cd} \text { and } \mathrm{Pb} \text {; } \\
\text { improved yield }\end{array}$ & [68] \\
\hline
\end{tabular}

Research conducted by different investigators suggests the amelioration of toxic effects of HMs by NPs via improvements in antioxidant defense enzymes, modifications in the expression of metal transporter genes, altered regulation of vital metabolic pathways, variation in metal accumulation/mobilization, maintenance of photosynthetic pigments, and reduction in growth inhibition under metal stress $[19,64,67,69]$.

\section{Alleviation of Salinity Stress in Plant Using Nanoparticles}

Salinity has emerged as a global concern due to steady increases in salt-affected land throughout the world [76]. For example, it is straddling from the Indo-Gangetic plain to the Great Hungarian Plain, Russia, Israel, China, and the United States of America [77,78]. The extent of salinity-affected areas is expected to cover about $50 \%$ of total agricultural land by 2050. Salinity stress causes various detrimental effects to plants' physiological, biochemical, and molecular features and reduces productivity [79]. These impacts and their consequences induced by salinity stress in plants are shown in Figure 1.

Nanoparticles can help the plant under salt stress by regulating ion balance; reducing the $\mathrm{Na}^{+}$ion toxicity; increasing the uptake of $\mathrm{K}^{+}$; activating the antioxidative defense system; increasing the contents of the pigment, compatible solutes; and increasing stomatal conductance. In salinity-stressed T. aestivum L., the application of magnetite NPs improved chlorophyll contents and antioxidative enzymes along with the amelioration of various polypeptide chains, which are reported to be linked with salinity stress tolerance [80]. Nano- $\mathrm{SiO}_{2}$ improved the growth of $\mathrm{G}$. max under salt stress by raising the level of leaf $\mathrm{K}^{+}$ and biological antioxidant activities [81]. Similarly, in salt-stressed T. aestivum L. cultivars, nano- $\mathrm{SiO}_{2}$ was found to improve seed germination and growth [82].

The application of Zn NPs to salt-stressed Brassica napus plants alleviated the salinityinduced detrimental impacts by upregulating the antioxidative mechanism, osmolyte biosynthesis, and ionic control [83]. In Solanum lycopersicum, Cu NPs applied to the leaves mitigated salinity stress by improving growth and the $\mathrm{Na}^{+} / \mathrm{K}^{+}$ratio. Moreover, $\mathrm{Cu} \mathrm{NPs}$ improved the level of glutathione, polyphenols, and vitamin $C$ content as compared to the control. Additionally, the activities of APX, GPX, and SOD were also modulated, thereby improving the overall plant's normal growth and development [84]. In addition, seed priming with $\mathrm{ZnO}$ NPs $(60 \mathrm{mg} / \mathrm{L})$ ameliorated the detrimental consequence induced by the $\mathrm{NaCl}$ treatment in Lupinus termis via increasing the pigments, osmoregulation, and regulation of the contents of stress-associated metabolites. In another study, the seed priming of T. aestivum L. with Ag NPs was also proven to be an adequate salinity stress management strategy [85]. 


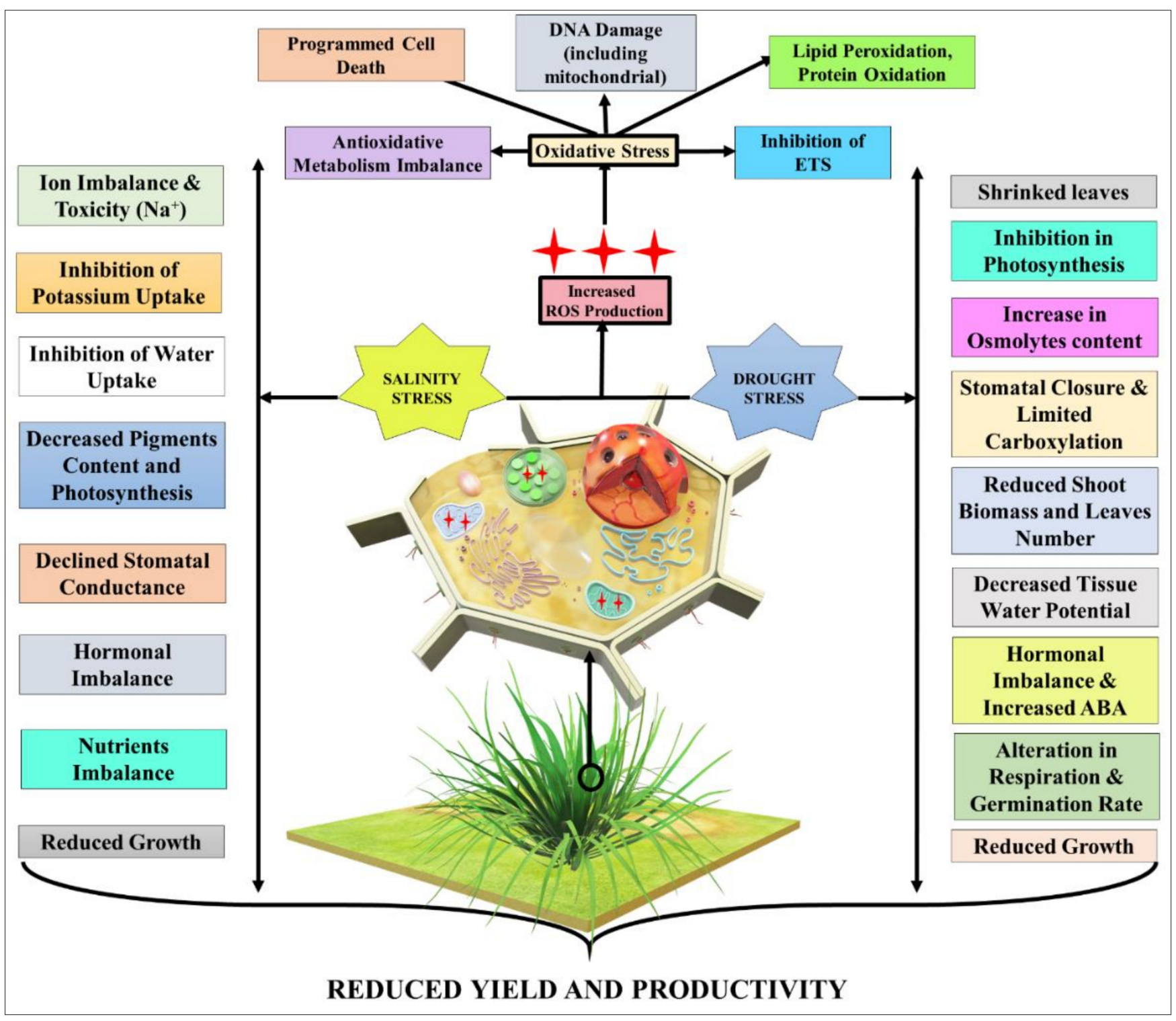

Figure 1. Salinity and drought stress-mediated responses in the plants; ETS: electron transport system.

Recently, a study depicted that the exogenous application of salicylic acid+nano- $\mathrm{Fe}_{2} \mathrm{O}_{3}$ to Trachyspermum ammi L. alleviated salinity stress to a considerable extent via increasing $\mathrm{K}^{+}$ uptake, $\mathrm{K}^{+} / \mathrm{Na}^{+}$ratio; iron content; activities of various antioxidative enzymes viz. SOD, catalase (CAT), peroxidase (POD), and phenol peroxidase (PPO); and the contents of the compatible solutes. These modifications collectively led to the improvement in membrane stability index, leaf water content, pigments, and growth of the plants (Table 2) [86]. 
Table 2. Applications of NPs in salinity stress mitigation by altering the morphophysiological responses of plants.

\begin{tabular}{|c|c|c|c|c|}
\hline Nanoparticles & Plants & $\begin{array}{c}\text { Germination and } \\
\text { Morphological Responses }\end{array}$ & Physiological Responses & References \\
\hline $\begin{array}{c}\operatorname{Ag}(0,2,5, \text { and } 10 \\
\mathrm{mM})\end{array}$ & Triticum aestivum $\mathrm{L}$. & $\begin{array}{l}\text { Seed priming with Ag NPs } \\
\text { significantly augmented the } \\
\text { fresh and dry biomass of salinity } \\
\text { stressed wheat plants at all doses } \\
\text { compared to the control. }\end{array}$ & $\begin{array}{l}\text { Ag NPs increased the activities of vital } \\
\text { antioxidative enzymes whilst declined } \\
\text { the contents of stress indicators, i.e., } \\
\text { MDA and } \mathrm{H}_{2} \mathrm{O}_{2} \text { in wheat leaves as } \\
\text { compared to salt stressed plants. }\end{array}$ & [85] \\
\hline $\begin{array}{l}\text { Zn-, B-, Si-, and } \\
\text { Zeolite NPs }\end{array}$ & $\begin{array}{l}\text { Solanum tuberosum L., } \\
\text { Diamont cultivar }\end{array}$ & $\begin{array}{l}\text { Application of individual and } \\
\text { binary treatment of NPs } \\
\text { improved plant height, shoot } \\
\text { dry weight, number of stems per } \\
\text { plant, and tuber yield as } \\
\text { compared to the control. }\end{array}$ & $\begin{array}{l}\text { NP treatment increased leaf relative } \\
\text { water content, leaf photosynthetic rate, } \\
\text { leaf stomatal conductance, and } \\
\text { chlorophyll content in comparison to } \\
\text { the control; improved nutrients } \\
\text { contents, leaf proline content, and leaf } \\
\text { gibberellic acid level; and enhanced the } \\
\text { contents of protein adn carbohydrates, } \\
\text { and antioxidative enzymes' activities. }\end{array}$ & [87] \\
\hline $\begin{array}{l}\text { Fe }(0,0.08 \text {, and } \\
0.8 \text { ppm }) \text {, and } \\
\text { potassium silicate } \\
(0,1, \text { and } 2 \mathrm{mM})\end{array}$ & Vitis vinifera & - & $\begin{array}{l}\text { Application of NPs significantly } \\
\text { increased the total protein content, } \\
\text { activities of antioxidative enzymes } \\
\text { (POD, CAT, and SOD), and hydrogen } \\
\text { peroxide, while reduced proline } \\
\text { content. }\end{array}$ & [88] \\
\hline $\begin{array}{c}\text { Fe }(0.0,0.08 \text {, and } \\
0.8 \mathrm{ppm})\end{array}$ & Fragaria ananassa & $\begin{array}{l}\text { Application of Fe NPs (at higher } \\
\text { concentrations) increased root } \\
\text { dry weight and dry weight of } \\
\text { the explants. }\end{array}$ & $\begin{array}{l}\text { Fe NPs improved the contents of } \\
\text { photosynthetic pigments and total } \\
\text { soluble carbohydrate, membrane } \\
\text { stability index, and relative water } \\
\text { content of salinity-stressed plants. }\end{array}$ & [89] \\
\hline $\begin{array}{l}\mathrm{N}-\mathrm{Na}_{2} \mathrm{SiO}_{3}(400 \\
\text { ppm) }\end{array}$ & S. tuberosum L. & $\begin{array}{l}\text { Foliar spraying of } \mathrm{N}-\mathrm{Na}_{2} \mathrm{SiO}_{3} \\
\text { restored the tuber number per } \\
\text { plant and tuber yield along with } \\
\text { improved water use efficiency } \\
\text { and tuber dry matter percentage } \\
\text { under salinity stress. }\end{array}$ & $\begin{array}{l}\text { Application of } \mathrm{N}-\mathrm{Na}_{2} \mathrm{SiO}_{3} \text { exerted } \\
\text { positive impacts on the quantum yield } \\
\text { of PS II, carotenoids content, and } \\
\text { DPPH radical scavenging activity in } \\
\text { salinity stressed plants. }\end{array}$ & [90] \\
\hline $\begin{array}{l}\mathrm{SiO}_{2}(0,50,100, \\
\text { and } 150 \mathrm{mg} / \mathrm{L})\end{array}$ & Musa acuminata & $\begin{array}{l}\text { All doses of } \mathrm{SiO}_{2} \mathrm{NPs} \text { improved } \\
\text { the number of shoots and shoot } \\
\text { length of banana. }\end{array}$ & $\begin{array}{l}\text { Application of } \mathrm{SiO}_{2} \mathrm{NPs} \text { increased } \\
\text { chlorophyll content, lowered } \\
\text { electrolyte leakage, reduced MDA } \\
\text { content, and altered the content of } \\
\text { phenolic compounds }\end{array}$ & [91] \\
\hline $\begin{array}{l}\text { CNPs }(0.3 \% \text { and } \\
90-110 \mathrm{~nm})\end{array}$ & Lactuca sativa & $\begin{array}{l}\text { The salinity-induced deleterious } \\
\text { effects on germination and } \\
\text { associated parameters were } \\
\text { alleviated by the exposure of C } \\
\text { NPs, e.g., treatment of C NPs for } \\
2 \mathrm{~h} \text { significantly improved the } \\
\text { germination rate in some } \\
\text { varieties. }\end{array}$ & - & [92] \\
\hline $\begin{array}{l}\mathrm{ZnO}(0,1000, \text { and } \\
3000 \mathrm{ppm})\end{array}$ & $\begin{array}{c}\text { Trigonella } \\
\text { foenum-graecum }\end{array}$ & 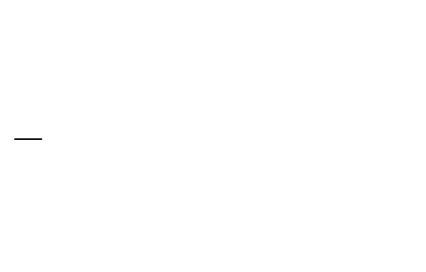 & $\begin{array}{l}\text { Interaction of } \mathrm{NaCl} \text { and } \mathrm{ZnO} \text { was } \\
\text { recorded to reverse the salinity } \\
\text { induced consequences (L-proline, } \\
\text { protein, MDA, aldehydes, sugars, } \\
\mathrm{H}_{2} \mathrm{O}_{2} \text {, and antioxidative enzymes) in } \\
\text { both cultivars, but the results were } \\
\text { more apparent in case cv. Ardestanian } \\
\text { than cv. Mashhadian. }\end{array}$ & [93] \\
\hline $\begin{array}{l}\mathrm{ZnO}(10,50, \text { and } \\
100 \mathrm{mg} / \mathrm{L})\end{array}$ & Lycopersicon esculentum & $\begin{array}{l}\text { Foliar spraying of } \mathrm{ZnO} N \mathrm{NPs} \\
\text { increased shoot length and root } \\
\text { length, biomass, and leaf area. }\end{array}$ & $\begin{array}{l}\text { Increased chlorophyll content and } \\
\text { photosynthetic attributes, protein } \\
\text { content, and activities of antioxidative } \\
\text { enzymes (POX, SOD, and CAT) in } \\
\text { salinity-stressed tomato plants. }\end{array}$ & [94] \\
\hline $\begin{array}{l}\mathrm{TiO}_{2},(40,60, \text { and } \\
80 \mathrm{ppm})\end{array}$ & Zea mays L. & $\begin{array}{l}\text { Seed priming with } \mathrm{TiO}_{2} \\
\text { positively impacted the } \\
\text { germination (germination } \\
\text { percentage, germination energy, } \\
\text { and seedling vigor index) and } \\
\text { seedling growth (lengths of root } \\
\text { and shoot, fresh, and dry weight) } \\
\text { and reduced the mean } \\
\text { emergence time. }\end{array}$ & $\begin{array}{l}\text { Results showed the enhancement in } \\
\text { potassium ion concentration, relative } \\
\text { water content, contents of total } \\
\text { phenolic and proline contents; } \\
\text { increased SOD, CAT, and PAL } \\
\text { activities; and decreased sodium ion } \\
\text { concentration, membrane electrolyte } \\
\text { leakage, and MDA content. }\end{array}$ & [53] \\
\hline
\end{tabular}




\section{Alleviation of Drought Stress in Plants Using Nanoparticles}

Drought stress is reported to have severe consequences for crops, including reduced leaf area, reduced growth, limited carboxylation, decreased water potential, hormonal imbalance, and oxidative stress $[95,96]$. It is frequently associated with high temperature due to increased water loss through evapotranspiration. Owing to this reason, plants reduce the leaf water and turgor pressure. These consequences are also associated with the stomatal closure, which in turn decelerates the plant's metabolism and ceases vital enzymatic reactions. In addition, the severe water shortages eventually contribute to stunted crop growth and finally death $[97,98]$.

An insight into the morphophysiological responses and consequences of plants against drought stress is presented in Figure 1. The key factors under drought stress are the severity and duration of the stress, which could be directly correlated with drought stress-induced loss in crop productivity and economic yield [99]. Furthermore, salinity combined with drought stress led to a decrease in water potential, but the osmotic potential decreased more significantly [100].

Applications of NPs to drought stress plants have been observed to improve photosynthetic rate, stomatal conductance, relative water content, and ameliorated cell membrane damage by lowering the contents of stress metabolites and electrolyte leakage. Furthermore, increases in osmolyte contents, carotenoid content, chlorophyll content, protein content, and phenolic substances (i.e., rosmarinic acid and chlorogenic acid) and improved activities of antioxidant enzymes such as CAT, SOD, and POX have also been found as a general mechanism in overcoming and mitigating drought stress.

The experimental outcomes of Ashkavand et al. [101] revealed the positive impacts of Si NPs on physiological parameters under drought stress. In another study, the application of nanoscale $\mathrm{TiO}_{2}$ improved the morphophysiological indices, especially at lower doses under water deficit environment, which subsequently improved the plant's performance [102]. The application of $\mathrm{TiO}_{2} \mathrm{NPs}$ in Dracocephalum moldavicum also upsurged the synthesis of some important metabolites such as rosmarinic acid, chlorogenic acid, acacetin7-O-glucoside, and apigenin-7-O-glucoside [103]. Zinc oxide NPs were also reported as potential novel fertilizers that can provide new horizons for the agricultural sector. The findings reported by Dimkpa et al. [104] indicated that $\mathrm{Zn}$ in nanoparticulate form can hasten the phenological development, reproductive yield, and nutrition in water-stressed cereal crops.

According to the research outcomes of Zahedi et al. [105], in drought-stressed Fragaria ananassa, the chlorophyll contents were improved after spraying Se and $\mathrm{SiO}_{2} \mathrm{NPs}$. The applications of these NPs also resulted in significant improvement in other physiological parameters such as MDA, $\mathrm{H}_{2} \mathrm{O}_{2}$, and antioxidative enzymes activities. Similarly, zerovalent $\mathrm{Cu}$ NPs showed the ameliorative roles against drought stress in $Z$. mays. The drought stress tolerance was imparted by maintaining the leaf water content; increasing the anthocyanin, chlorophyll, and carotenoids contents; and enhancing the ROS scavenging potential [106].

Moreover, the exogenous exposure of ZnO NPs to drought stressed Solanum melongena caused an increase in relative water content and membrane stability index that was observed to be related with the improved stem, leaf anatomical features (vascular cylinder thickness, dimensions of the pith, cortex thickness, and leaf blade), and plant's photosynthetic efficiency [107]. Therefore, an extensive literature survey was also performed to explicate the positive influences of NPs on edible plants that are grown under drought stressed environment (Table 3). 
Table 3. Applications of nanoparticles in drought stress mitigation by altering the morphophysiological responses of plants.

\begin{tabular}{|c|c|c|c|c|}
\hline Nanoparticles & Plants & $\begin{array}{l}\text { Germination and } \\
\text { Morphological } \\
\text { Responses }\end{array}$ & Physiological Responses & References \\
\hline $\begin{array}{l}\text { Silica }(0,10,50 \text {, and } \\
100 \mathrm{mg} / \mathrm{L})\end{array}$ & & $\begin{array}{l}\text { S NPs increased plant } \\
\text { biomass and xylem } \\
\text { water potential in } \\
\text { drought-stressed } \\
\text { seedlings. }\end{array}$ & $\begin{array}{l}\text { S NPs improved the } \\
\text { photosynthetic rate and stomatal } \\
\text { conductance considerably; no } \\
\text { effects were recorded on MDA } \\
\text { content, relative water content, } \\
\text { and electrolyte leakage index; } \\
\text { carbohydrate and proline } \\
\text { content under drought stress } \\
\text { declined. }\end{array}$ & [101] \\
\hline $\begin{array}{c}\mathrm{TiO}_{2}(0,10,100, \text { and } \\
500 \mathrm{mg} / \mathrm{L} \text {, and } 10-25 \\
\mathrm{~nm})\end{array}$ & Linum usitatissimum L. & $\begin{array}{l}\text { Number of capsules } \\
\text { per plant increased in } \\
\text { plants under the } \\
\text { application of } \mathrm{TiO}_{2} \text { as } \\
\text { compared to control } \\
\text { and enhanced the seed } \\
\text { weight. }\end{array}$ & $\begin{array}{l}\text { Nano- } \mathrm{TiO}_{2} \text { treatment of } \\
\text { drought-stressed plants surged } \\
\text { carotenoids content and } \\
\text { ameliorated cell membrane } \\
\text { damage, and seed oil and } \\
\text { protein contents (at } 100 \mathrm{mg} / \mathrm{L} \text { ) } \\
\text { compared to normal. }\end{array}$ & [102] \\
\hline $\begin{array}{l}\text { Chitosan }(0,30,60 \text {, and } \\
90 \mathrm{ppm})\end{array}$ & Triticum aestivum L. & $\begin{array}{l}\text { Foliar spraying of C } \\
\text { NPs (particularly at } 90 \\
\text { ppm) at tillering, stem } \\
\text { elongation, and } \\
\text { heading stages caused } \\
\text { increase in leaf area, } \\
\text { crop yield, and biomass } \\
\text { as compared to the } \\
\text { control. }\end{array}$ & $\begin{array}{l}\text { Application of C NPs increased } \\
\text { relative water content, } \\
\text { chlorophyll content, } \\
\text { photosynthetic rate, and CAT } \\
\text { and SOD activities in } \\
\text { comparison to the control. }\end{array}$ & [108] \\
\hline $\begin{array}{c}\mathrm{TiO}_{2}(0,5,10,20,30,50 \\
100, \text { and } 150 \text { ppm })\end{array}$ & $\begin{array}{l}\text { Dracocephalum } \\
\text { moldavica } \mathrm{L} .\end{array}$ & $\begin{array}{l}\mathrm{TiO}_{2} \text { treatment had no } \\
\text { significant impact on } \\
\text { the plant dry weight }\end{array}$ & $\begin{array}{l}\left.\mathrm{TiO}_{2} \text { application ( } 30-50 \mathrm{ppm}\right) \\
\text { increased certain beneficial } \\
\text { phenolic substances (rosmarinic } \\
\text { acid and chlorogenic acid) in } \\
\text { stressed plants. }\end{array}$ & [103] \\
\hline $\begin{array}{c}\mathrm{Si}(0,25,50, \\
\text { and } 100 \mathrm{mg} / \mathrm{kg})\end{array}$ & T. aestivum L. & $\begin{array}{l}\text { Treatment of Si NPs to } \\
\text { drought-stressed plant } \\
\text { grown in Cd } \\
\text { contaminated soil } \\
\text { showed maximum } \\
\text { values of shoot, root, } \\
\text { and grain dry biomass, } \\
\text { i.e., } 70 \%, 54 \% \text {, and } 75 \% \text {, } \\
\text { respectively (at } 100 \\
\mathrm{mg} / \mathrm{kg} \text { ). }\end{array}$ & $\begin{array}{l}\text { Application of Si NPs } \\
\text { significantly improved the } \\
\text { contents of chlorophyll and } \\
\text { ameliorated oxidative stress by } \\
\text { lowering the content of MDA, } \\
\mathrm{H}_{2} \mathrm{O}_{2} \text {, and electrolyte leakage. }\end{array}$ & [65] \\
\hline $\begin{array}{c}\text { Fe }(25,50, \text { and } 100 \\
\mathrm{mg} / \mathrm{kg})\end{array}$ & T. aestivum L. & $\begin{array}{l}\text { Application of Fe NPs } \\
\text { increased plant height, } \\
\text { spike length, and dry } \\
\text { weight under drought } \\
\text { stress over control. }\end{array}$ & $\begin{array}{l}\text { Chlorophyll a content increased } \\
\text { up to } 66 \% \text { in wheat plants } \\
\text { compared to the respective } \\
\text { controls and eradicated the } \\
\text { oxidative stress by switching } \\
\text { antioxidative defense system. }\end{array}$ & {$[30]$} \\
\hline $\mathrm{ZnO}(1.0 \%)$ & T. aestivum $\mathrm{L}$. & $\begin{array}{l}\text { Application of } \mathrm{ZnO} \\
\text { NPs strongly alleviated } \\
\text { the delay in panicle } \\
\text { initiation time and } \\
\text { significantly increased } \\
\text { grain yield as } \\
\text { compared to the control } \\
\text { under drought stress. }\end{array}$ & $\begin{array}{l}\text { ZnO NPs enhanced } \mathrm{Zn} \text { uptake } \\
\text { but could not mitigate the } \\
\text { negative impacts of drought } \\
\text { stress on } \mathrm{N} \text { and } \mathrm{P} \text { uptake in } \\
\text { wheat plants. }\end{array}$ & [104] \\
\hline
\end{tabular}


Table 3. Cont.

\begin{tabular}{|c|c|c|c|c|}
\hline Nanoparticles & Plants & $\begin{array}{l}\text { Germination and } \\
\text { Morphological } \\
\text { Responses }\end{array}$ & Physiological Responses & References \\
\hline $\begin{array}{c}\mathrm{ZnO}(50,100, \text { and } \\
150 \mathrm{mg} / \mathrm{L}) \text { and } \mathrm{Si}(150 \\
\text { and } 300 \mathrm{mg} / \mathrm{L})\end{array}$ & Mangifera indica L. & $\begin{array}{l}\text { Increased leaf area } \\
\text { improved the total } \\
\text { yield and fruit } \\
\text { physiochemical } \\
\text { characteristics as } \\
\text { compared to the control } \\
\text { under both NPs } \\
\text { treatments. }\end{array}$ & $\begin{array}{l}\text { Application of both NPs } \\
\text { enhanced leaf NPK content; total } \\
\text { carbohydrates, total sugars, and } \\
\text { proline content; and SOD, POX, } \\
\text { and CAT activities (at } 100 \mathrm{mg} / \mathrm{L} \\
\text { nZnO and } 150 \mathrm{mg} / \mathrm{L} \mathrm{nSi} \text { ) over } \\
\text { the control. }\end{array}$ & [109] \\
\hline $\begin{array}{c}\mathrm{ZnO} \\
(0,25,50, \text { and } \\
100 \mathrm{mg} / \mathrm{L})\end{array}$ & T. aestivum L. & $\begin{array}{l}\text { Application of } \mathrm{ZnO} \\
\text { NPs improved } T \text {. } \\
\text { aestivum L. growth and } \\
\text { crop yield. }\end{array}$ & $\begin{array}{l}\text { Foliar spray enhanced } \\
\text { chlorophyll content, and the } \\
\text { activities of SOD and POXs. }\end{array}$ & [110] \\
\hline $\begin{array}{c}\mathrm{SiO}_{2} \text { NPs, Se NPs, and } \\
\mathrm{SiO}_{2} / \mathrm{Se} \mathrm{NPs}(50 \text { and } \\
100 \mathrm{mg} / \mathrm{L})\end{array}$ & $\begin{array}{c}\text { Fragaria } \times \text { ananassa } \\
\text { Duch. }\end{array}$ & $\begin{array}{l}\text { Spraying of different } \\
\text { NPs improved the } \\
\text { growth and yield } \\
\text { parameters of } \\
\text { drought-stressed } \\
\text { strawberry plants. }\end{array}$ & $\begin{array}{l}\text { Treatment of } \mathrm{Se} / \mathrm{SiO}_{2} \text { at } 100 \\
\text { mg/L showed maximal benefits } \\
\text { to plants by preserving more } \\
\text { photosynthetic pigments } \\
\text { comparatively and increased } \\
\text { relative water content, } \\
\text { membrane stability index, and } \\
\text { water use efficiency. Spraying of } \\
\mathrm{Se} / \mathrm{SiO}_{2} \text { also increased drought } \\
\text { tolerance via increasing the } \\
\text { activities of } \mathrm{CAT}, \mathrm{APX}, \mathrm{GPX} \text {, and } \\
\text { SOD and decreased lipid } \\
\text { peroxidation and } \mathrm{H}_{2} \mathrm{O}_{2} \text { content. }\end{array}$ & [105] \\
\hline $\begin{array}{c}\text { Zero-valent copper } \\
\text { NPs }(3.333,4.444 \text {, and } \\
5.556 \mathrm{mg} / \mathrm{L})\end{array}$ & Zea mays & $\begin{array}{l}\text { Cu NPs improved the } \\
\text { biomass of } \\
\text { drought-stressed } \\
\text { plants, and increased } \\
\text { total seed number and } \\
\text { grain yield of maize } \\
\text { plants. }\end{array}$ & $\begin{array}{l}\text { Treatment of Cu NPs increased } \\
\text { the contents of anthocyanin, } \\
\text { chlorophyll, and carotenoid and } \\
\text { improved drought stress } \\
\text { tolerance by decreasing the } \\
\text { oxidative stress via the } \\
\text { enhancement of ROS scavenging } \\
\text { antioxidative enzymes. }\end{array}$ & [106] \\
\hline $\begin{array}{l}\mathrm{ZnO} \text { NPs (50 and } \\
100 \mathrm{ppm})\end{array}$ & Solanum melongena $\mathrm{L}$. & $\begin{array}{l}\text { Foliar spray of } \mathrm{ZnO} \\
\text { NPs improved the } \\
\text { plant growth and } \\
\text { productivity. }\end{array}$ & $\begin{array}{l}\text { Application of ZnO NPs } \\
\text { improved macro- and } \\
\text { micronutrients' uptake and } \\
\text { increased relative water content } \\
\text { in plants under drought stress. }\end{array}$ & [107] \\
\hline
\end{tabular}

\section{Mechanism of Stress Alleviation in Plants under Nanoparticles Application}

This section investigates the influence of NPs on enzymatic and non-enzymatic components and how the interaction of NPs with these components helps the plant in coping with stress conditions. This section also discusses the impacts of NPs on a plant's secondary metabolism, the activation of the salt overly sensitive (SOS) pathway, the roles of abscisic acid under salt stress, and molecular insights.

\subsection{Impact on Antioxidative Enzymes}

During oxidative stress, SOD helps in the removal of superoxide $\left(\bullet \mathrm{O}_{2}{ }^{-}\right)$by catalyzing dismutation reaction and by converting it into $\mathrm{O}_{2}$ and $\mathrm{H}_{2} \mathrm{O}_{2}$. The CAT, POX, and GPX metabolize and carry out the conversion of $\mathrm{H}_{2} \mathrm{O}_{2}$ into water and $\mathrm{O}_{2}$. Together, SOD, CAT, POX, and GPX prevent the formation of more harmful ROS (such as hydroxyl radicals) via a Haber Weiss reaction. Furthermore, the Foyer-Halliwell-Asada pathway (also known as the ascorbate-glutathione pathway), which involves enzymes such as glutathione reductase 
(GR), APX, monodehydroascorbate reductase (MDHAR), and dehydroascorbate reductase (DHAR), also reduce $\mathrm{H}_{2} \mathrm{O}_{2}$ after utilizing the reducing potential of NADPH (Table 4).

The SOD enzyme is present in three different isoforms in plants. i.e., $\mathrm{Cu} / \mathrm{Zn}-\mathrm{SOD}$ (in cytoplasm, peroxisomes, chloroplasts, and apoplasts), Fe-SOD (in chloroplasts), and Mn-SOD (in mitochondria and peroxisomes) [8]. In an experiment, it was revealed that, when $\mathrm{Cu}$ NPs were applied to hydroponically grown Cucumis sativus, the gene expression level of $\mathrm{Cu} / \mathrm{Zn}-\mathrm{SOD}$ increased by up to six-fold under $50 \mathrm{mg} / \mathrm{L} \mathrm{Cu}$ NPs treatment [111]. In this study, the biomass of $C$. sativus was found to be reduced under NPs treatment and plant was found under stress conditions, leading to increased activity of the SOD [111]. However, in another report, it was observed that the treatment of $\mathrm{ZnO}$ NPs decreased the activity of SOD in Cicer arietinum [112]. In this study, ZnO NPs were found to be beneficial for $C$. arietinum growth and reduced ROS levels [112]. Therefore, the differences in the change in the activity of SOD in (C. sativus and C. arietinum) were due to the different responses of the plant to these NPs.

In another study, the beneficial role of ZnO NPs was observed in comparison to the bulk $\mathrm{ZnO}$ for three different vegetable crops, i.e., B. oleracea var. capitata, B. oleracea var. botrytis, and S. lycopersicum [113]. It was found that treatment with ZnO NPs increased the germination, growth, and biochemical parameters of these crops in comparison to the bulk $\mathrm{ZnO}$. The $\mathrm{ZnO}$ NPs were found to induce the activity of antioxidant enzymes such as SOD, CAT, APX, and guaiacol peroxidase (POD) along with the pigments, sugar, and protein contents in these three crops. However, the activities of these enzymes were even higher under bulk $\mathrm{ZnO}$, indicating that the activities of these enzymes are influenced by physiological state and oxidative stress within plant cells, and bulk $\mathrm{ZnO}$ was found to exert more stress in these horticultural crops. These findings suggest that changes in the activity and gene expression level of SOD were influenced by the overall biochemical state of the plant cell rather than metallic NPs directly influencing SOD activity. However, more evidence is required to support the hypothesis. In another report, it was revealed that, when Se NPs and $\mathrm{Cu}$ NPs were applied on S. lycopersicum, it resulted in an increased yield; better contents of chlorophyll, vitamin C, and glutathione; and increased activity of SOD, GPX, and phenylalanine ammonia-lyase (PAL) [114].

Thus, in this study, the physiological parameter showed a better state of the health condition in the plant cell. In a similar study, ZnO NPs were applied to Leucaena leucocephala along with phosphorus [70]. In this study, plant biomass, chlorophyll, carotenoid, and protein content were found to be increased significantly. In contrast, the activities of SOD and POX were also found to be high.

However, the exploration of how the antioxidant enzymes are relatively more active during such NP treatments is required. However, it is still uncertain whether the applications of Se NPs, Cu NPs, or ZnO NPs have direct effects on the activities of these enzymes or whether the activities of these enzymes under NPs stress are accountable for the plant's improved physiological condition and yield. Therefore, more investigations are required to fully comprehend the mechanisms behind the interaction of the NPs with these antioxidant enzymes.

In one study, when Cu-chitosan NPs were applied to boost defense responses against Curvularia leaf spot (CLS) disease in Z. mays, it was observed that application of NPs induced the activity of antioxidant enzymes (SOD and POD) and defense enzymes such as PAL and polyphenol oxidase (PPO) [115]. This study highlights the application of $\mathrm{Cu}$-chitosan NP-induced innate immunity by the elicitation of the plant defense and antioxidant system for disease protection, thereby promoting plant growth [115]. Similarly, $\mathrm{ZnO}$ NPs coated with phytomolecules were also found to promote the growth (by $125.4 \%$ ), biomass (by 132.8\%), pigment, and protein content of the Gossypium hirsutum plants [116]. Furthermore, this study reported that there was a significant increase in the activities of SOD $(267.8 \%)$ and POX (174.5\%) but a decrease in the activity of catalase (CAT, 83.2\%) in the NP-treated plants as compared to the control [117]. These findings suggest that $\mathrm{ZnO}$ NPs coated with biomolecules can have a significant positive impact on the health 
of the plant cell and can boost the immunity of the plant by increasing the activity of the antioxidant enzymes.

The nanoform of a micronutrient acts as an elicitor in activating antioxidant enzymes and therefore increases the tolerance capacity of the plant to various kinds of stress conditions. To prove this, an experiment was conducted, where the nanoform of $\mathrm{TiO}_{2}$ was compared to its bulk form to understand the impact on antioxidant enzymes in Hyoscyamus niger [118]. It was observed that both SOD and POX enzyme activities were higher in nanoform-treated plants than that of the bulk form, except CAT activity. [118]. Therefore, it must be thoroughly studied further to clearly understand the influence of the NPs with reference to antioxidant enzymes.

\subsection{Impact on Cellular Osmolyte Pool}

The role of the non-enzymatic component has also been investigated under the influence of NP treatment. The activity of the antioxidant enzymes was correlated with the proline content, which acts as a non-enzymatic defense molecule in the plant cell. The growth, photosynthetic efficiency, and antioxidant system increased along with proline content in S. lycopersicum treated with ZnO NPs. Thus, the improved antioxidant defense system and proline accumulation could provide stability to $S$. lycopersicum [119]. The biochemical responses of $S$. lycopersicum grown under salt stress were investigated after the foliar application of $\mathrm{Cu}$ NPs, and it was revealed that oxidative damage due to salt stress can be mitigated by application of $\mathrm{Cu}$ NPs. It was observed that the activity of enzymatic (APX, GPX, SOD, and CAT) and non-enzymatic components (phenol, vitamin $\mathrm{C}$, and glutathione) both helped in increasing the stress tolerance in S. lycopersicum [84].

The phytotoxicity of $\mathrm{Al}$ in acidic soil was ameliorated after the application of nano$\mathrm{SiO}_{2}$ in Z. mays [120]. It is important to note that NP treatment did not influence $\mathrm{Al}$ accumulation; rather, it induced the enzymatic (SOD, CAT, APX, GPX, and GST) and non-enzymatic (ascorbate, glutathione, polyphenols, flavonoids, and tocopherols) defense systems of the plant to mitigate Al toxicity [120]. Moradbeygi [121] investigated the impact of FeO NPs on Dracocephalum moldavica growing under salinity stress. It was observed that, due to salinity stress, plants exhibited a decrease in leaf area. However, after the application of $\mathrm{FeO}$ NPs, plants were able to tolerate salinity stress due to the increased activity of antioxidant defense enzymes as well as an increase in the concentration of nonenzymatic components. Total phenolics, flavonoids, and anthocyanin content as well as the activity of the guaiacol peroxidase (GOPX), APX, CAT, and GR enzymes were enhanced. The application of FeO NPs significantly increased the leaf area in the plants under salt stress [121]. Similarly, in another study, nano-silicon when applied to G. max under salt stress led to increases in CAT, POX, APX, and SOD enzyme activities along with increases in concentration of phenolic components, ascorbic acid, and $\alpha$-tocopherol contents, thereby improving the salt tolerance [122].

These studies demonstrated that the use of nano fertilizers can be an effective strategy to overcome various abiotic stresses in the plants. Many of the non-enzymatic components also serve as high value compounds (such as flavonoids, phenolics acids, alkaloids, and carotenoids) for various downstream applications. The potential of NPs treatment in eliciting the production of these bioactive compound have been reviewed recently by Rivero-Montejo et al. [123]. These studies comprehensively signify the role of nonenzymatic components of the antioxidant defense system of the plants under NP influence (Figure 2). 


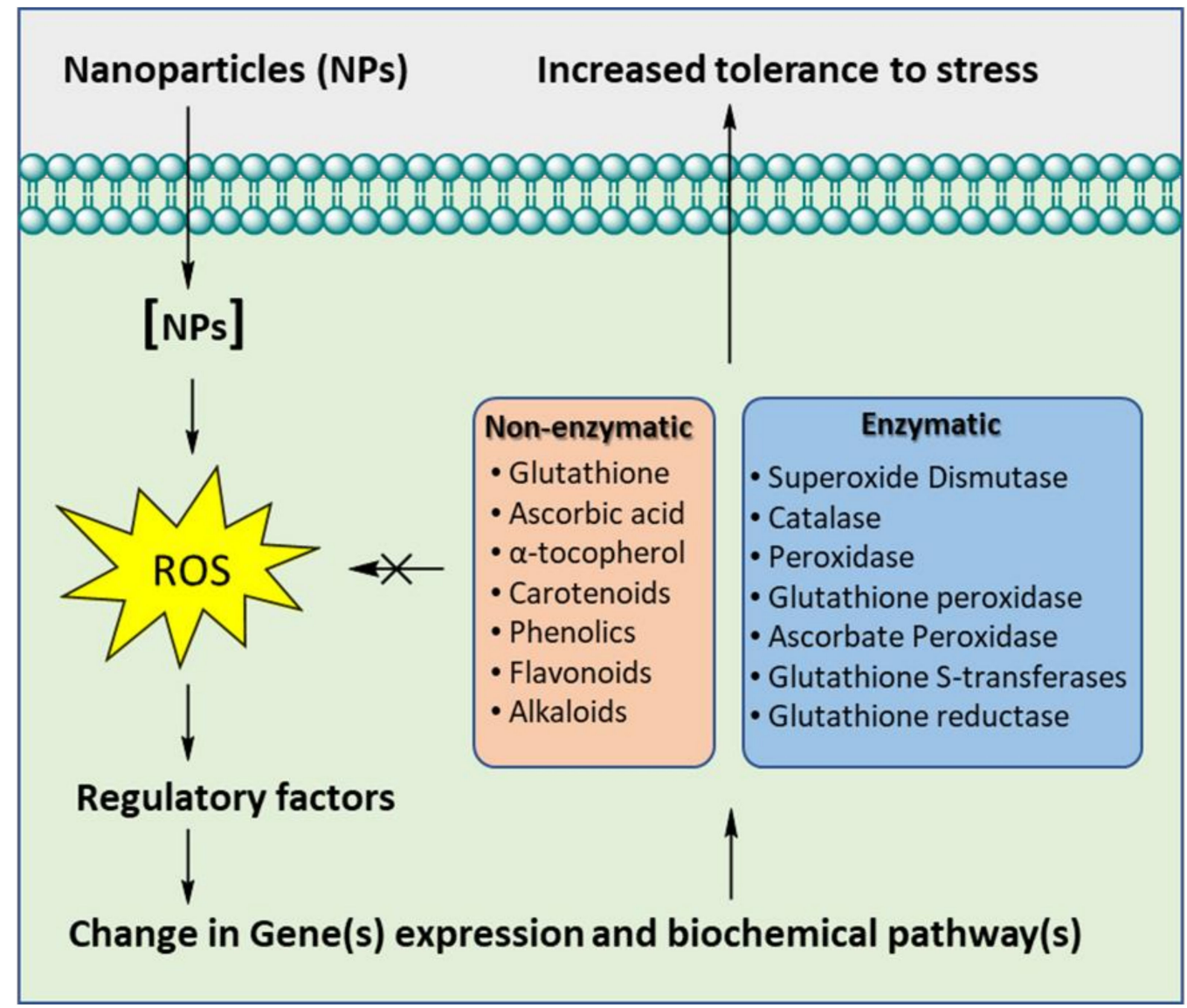

Figure 2. Schematic representation of elicitation of the enzymatic and non-enzymatic antioxidant defense mechanisms of plants by nanoparticles.

\subsection{Molecular Insights}

The miRNAs are important in almost all aspects of normal plant growth and production as well as in response to environmental variations such as light, nutrients, and various abiotic and biotic stresses [124]. In this context, the interaction of NPs with miRNAs was also recorded to alleviate several abiotic stress-induced consequences. For instance, the treatment of $\mathrm{TiO}_{2} \mathrm{NPs}$ at low doses to tobacco plants caused the upregulation of miRNA under metal stress; however, increased levels of NPs caused wilting, reduced biomass, leaf sizes, and leaf numbers as well as decreased root development [125]. The transcriptional responses of plants (Arabidopsis sp.) treated with Ag NPs were recorded using whole genome cDNA expression microarrays. The outcome of this work revealed that there was the upregulation of several genes (286), which are commonly reported to be associated with metal and oxidative stress [126]. It is documented that the NP-mediated benefits for plants relied on their association and absorption, which leads to several changes at the molecular level that ultimately influences the plant's physiology [127].

The impacts of Ce NPs on Gossypium under salinity stress were investigated in terms of the morphophysiological, biochemical, and molecular pathways. The research outcomes of this study revealed that there was an increase in biomass and development as well as a differential root transcripts expression in response to seed priming with Ce NPs [128]. However, there are only few papers that describe the plant-NP interaction at the molecular level; therefore, there is a great scope of research in this area for the application of NPs in the agricultural sector by modulating the molecular aspects of plants. According to a study, new plant genetics approaches based on NP-mediated clustered regularly interspersed palindromic repeats (CRISPR)-associated protein technology, similar to those in other biological systems, can deliver ground-breaking innovation. 


\subsection{Impact on Secondary Metabolites}

Stimulation in the secondary metabolites (terpenoids, phenolic compounds, alkaloids, etc.) under NPs treatment has been observed as one of the abiotic stress mitigation strategies. The levels of some phenolic compounds were increased in Hordeum vulgare after the exposure of CdO NPs for 3 weeks [129]. Similarly, the application of ZnO NPs increased the total phenolics and anthocyanin content in the Solanum tuberosum [130]. Likewise, $\mathrm{ZnO}$ NPs were found to induce the production of secondary metabolites, especially flavonoid contents in Echinacea purpurea [131]. Such an increased flavonoid content in the extract of Echinacea purpurea was found to exert anticancer properties. The NPs can be considered as elicitors for the production of secondary metabolites, and this potential has been explored by Modarresi et al. [132]. In this study, a significant increase in the total flavonoid and total alkaloid content (particularly glaucine, quercetin, and kaempferol) was observed in Nigella arvensis plants after treatment with different $\mathrm{NPs}$ such as $\mathrm{TiO}_{2}, \mathrm{Al}_{2} \mathrm{O}_{3}$, and $\mathrm{NiO}$ [132]. However, more investigations are required to understand if such an increase in anthocyanin, flavonoid, and alkaloid contents under NP influence has a beneficial role for the plant to cope with the abiotic stress conditions.

The application of nano- $\mathrm{ZnO}(100 \mathrm{mg} / \mathrm{L})$ in Z. mays enhanced the synthesis of melatonin and activated the antioxidative enzymes, which alleviated drought-induced consequences. These benefits related with the upregulation of SODs, APX, CAT, TDC (tryptophan decarboxylase), T5H (tryptamine 5-hydroxylase), SNAT (serotonin N-acetyltransferase), N-acetyl serotonin O-methyltransferase (ASMT), and COMT (caffeic acid O-methyltransferase) [133]. Likewise, the drought-stressed Punica granatum treated with Se NPs by foliar spraying showed higher levels of pigments, phenolic content, osmolytes, antioxidant enzymes, and abscisic acid than untreated ones [134].

\subsection{Activation of Salt Overly Sensitive (SOS) Pathway and Roles of Abscisic Acid under Salt Stress}

There are several studies that have demonstrated the significant roles of the SOS pathway in the maintenance of ionic homeostasis at the cellular level and salt tolerance [135]. Briefly, the SOS signaling pathway consists of three main proteins, namely, SOS1, SOR2, and SOS3 (Figure 3). The SOS1 gene encodes a plasma membrane antiporter $\left(\mathrm{Na}^{+} / \mathrm{H}^{+}\right)$ that regulates $\mathrm{Na}^{+}$efflux along with the distant transport of $\mathrm{Na}^{+}$from the roots [136]. It is further characterized by a long C-terminal that comprises the putative nucleotide-binding motif plus autoinhibitory domain. The SOS2 is reported to encode a serine/threonine kinase that is activated by elicited $\mathrm{Ca}^{+}$signals induced by salt stress [137]. The C-terminal regulatory domain of SOS2 protein contains a FISL motif. The third component of the SOS pathway is SOS3 protein that is a myristoylated $\mathrm{Ca}^{+}$binding protein and possesses a myristoylation site at its $\mathrm{N}$-terminus (important for salt tolerance). This motif acts as a site of interaction for $\mathrm{Ca}^{+}$binding of SOS3 protein. The interaction of SOS2 and SOS3 proteins results in the activation of kinases that phosphorylates SOS1. Under salinity stress, the increase in $\mathrm{Na}^{+}$leads to a sharp increase in $\mathrm{Ca}^{+}$[138].

Applications of NPs may activate the SOS signaling pathway, which is a crucial mechanism for $\mathrm{Na}^{+}$exclusion and ionic homeostasis in salinity-stressed plants, whilst the information is too scarce to reach definite conclusions in this milieu. For instance, the supplementation of multi-walled carbon nanotubes (MWCNTs) with the treatment of carbon nanotube in B. oleracea var. italica under salt stress conditions resulted in alterations in root plasmalemma permeability as well as improved aquaporin transduction [139]. In another study, the application of MWCNTs was observed to induce modulation in the genes of SOS1 in salt-stressed plants of B. napus L. [140]. Contrarily, other mechanisms are also observed to operate in blocking the bypass route of $\mathrm{Na}^{+}$in salinity-stressed plants by the treatment as a protective strategy. The research outcomes of some studies demonstrated the roles of $\mathrm{Si}$ in the obstruction of $\mathrm{Na}^{+}$uptake by silicate polymerization in the exodermis and endodermis, enhanced lignification along with suberization, and Casparian band's formation [141-143]. 


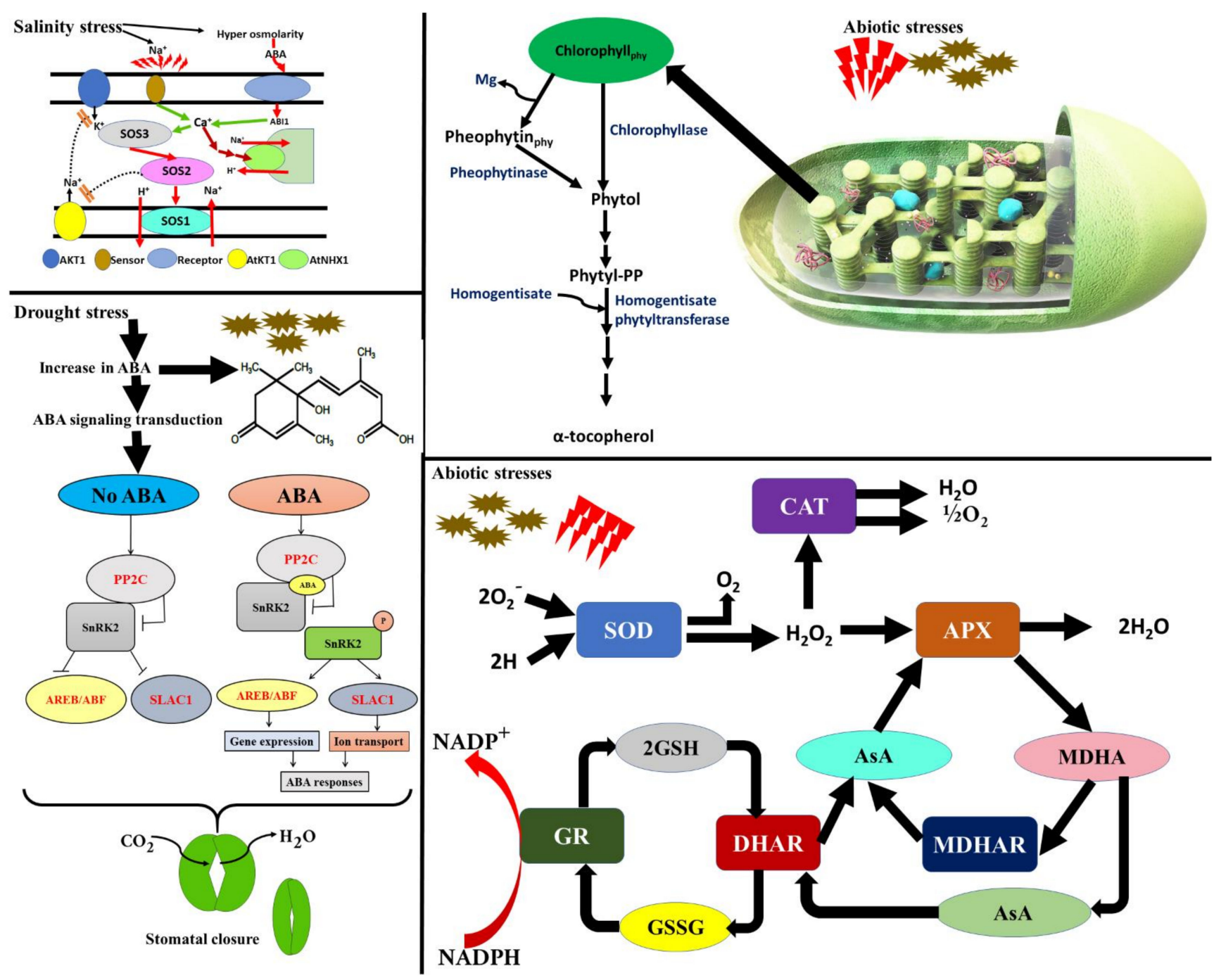

Figure 3. Schematic presentation of the underlying pathways that regulates the plant's responses under a stressed environment.

Abscisic acid (ABA) is characterized as a stress hormone, accumulates in response to stress, and mediates numerous stress responses to acclimatize the plants accordingly. It is well reported to participate in water-limited environments that can be the result of drought and salinity stresses. ABA is essential to the regulation of water deficit in plants and to the induction of genes by such enzymes and other proteins that are tolerant to cell dehydration [144].

In the ABA-dependent pathway, it binds with its receptors, i.e., Pyrabactin Resistance Protein1/PYR-like Proteins (RCAR/PYR1/PYLs), and belongs to the START-domain superfamily of proteins [145]. In plants, receptors of RCAR/PYR/PYL are reported to be in the cytoplasm and nucleus. As this hormone binds to RCAR/PYR/PYLs, the inactivation of type $2 \mathrm{C}$ protein phosphatases (PP2Cs) takes place. This subsequently causes the suppression of PP2C-mediated dephosphorylation of Sucrose nonfermenting Kinase-1-Related protein kinase 2s (SnRK2s) [95].

Thus, an activated SnRK2s switches the ABA-dependent gene expression and ion channels that help the plants cope with the stress. On the other hand, in ABA-independent pathway, PP2Cs are observed to dephosphorylate SnRK2s inhibiting the kinase activity, which prevents downstream gene expression [144,145].

The ABA was entrapped in monodispersed mesoporous silica (MSN) NPs (diameters $\approx 20 \mathrm{~nm}$; pore sizes $\approx 2.87 \mathrm{~nm}$ ) in which pore the entrances of MSNs were covered with 
decanethiol gatekeepers via GSH-cleavable disulfide linkages. In this work, the treatment of MSNs with redox-responsive gatekeepers was applied to drought-stressed Arabidopsis seedlings. The results showed that the usage of ABA in this controllable way can provide stress mitigation benefits [146].

Table 4. Some recent studies on the use of nanoparticles influencing the antioxidant defense system of the plant.

\begin{tabular}{|c|c|c|c|}
\hline Nanoparticles & Plant Name & Biochemical Changes/Significant Findings & References \\
\hline $\mathrm{Ag}$ & Pennisetum glaucum & $\begin{array}{l}\text { Seed priming with Ag NPs increased the activity of } \\
\text { antioxidant enzymes, proline content, total phenolics } \\
\text { and flavonoid contents in pearl millet. Ion homeostasis } \\
\text { is maintained by decreasing the sodium }\left(\mathrm{Na}^{+}\right) \text {and } \\
\mathrm{Na}^{+} / \mathrm{K}^{+} \text {ratio, while potassium }\left(\mathrm{K}^{+}\right) \text {increased by NPs } \\
\text { leading to increased salt tolerance. }\end{array}$ & [147] \\
\hline $\mathrm{Si}$ & Coriandrum sativum & $\begin{array}{l}\text { Si NPs are found to have a beneficial effect on } \\
\text { coriander under Pb stress. Foliar application of Si NPs } \\
\text { alleviated the adverse impacts of Pb by modulating the } \\
\text { vitamin C, flavonoids, antioxidant enzyme activities } \\
\text { (CAT, POD, and SOD), and malondialdehyde (MDA) } \\
\text { and by minimizing the oxidative stress. }\end{array}$ & [18] \\
\hline $\mathrm{Co}_{3} \mathrm{O}_{4}$ & Brassica napus & $\begin{array}{l}\text { Low concentrations of } \mathrm{Co}_{3} \mathrm{O}_{4} \mathrm{NP} \text { treatment induced a } \\
\text { beneficial effect on growth parameters by modulating } \\
\text { APX, SOD, CAT, GR, phenylalanine ammonia lyase } \\
\text { (PAL), tyrosine ammonia lyase (TAL), polyphenol } \\
\text { oxidase (PPO), Guaiacol peroxidase (GPX), and } \\
\text { glutathione S-transferase (GST) activity. }\end{array}$ & [148] \\
\hline $\mathrm{Fe}_{3} \mathrm{O}_{4}$ & Zea mays & $\begin{array}{l}\text { A beneficial role of NPs on root development and } \\
\text { membrane integrity is reported. Root length of maize } \\
\text { plant significantly increased after NP treatment, with } \\
\text { decreased malondialdehyde (MDA) level. NPs was } \\
\text { also found to inhibit the pathways related to } \\
\text { antioxidant defense. }\end{array}$ & [149] \\
\hline $\mathrm{ZnO}$ & Solanum lycopersicum & $\begin{array}{l}\text { Application of ZnO NPs led to increased tolerance in } \\
\text { tomato plant towards Tomato mosaic virus (ToMV). } \\
\text { Treatment of NPs led to increased growth parameters; } \\
\text { photosynthesis; increases in the activity of enzymatic } \\
\text { antioxidant defense systems (CAT, SOD, POX, APX, } \\
\text { GR, and lipoxygenase (LOX) activity); and the } \\
\text { accumulation of phenolic compounds, ascorbic acid } \\
\text { content, and proline production. }\end{array}$ & [150] \\
\hline $\mathrm{Al}_{2} \mathrm{O}_{3}$ and $\mathrm{NiO}$ & Nigella arvensis & $\begin{array}{l}\text { Activity of antioxidant enzymes such as APX, CAT, } \\
\text { SOD, and POD are found to increase. Total antioxidant } \\
\text { capacity, reducing power, iridoids content, saponin } \\
\text { content, and phenolic content are also found to be } \\
\text { higher in plants treated with } \mathrm{Al}_{2} \mathrm{O}_{3} \mathrm{NPs}(100-2500 \\
\mathrm{mg} / \mathrm{L}) \text { and low concentrations }(<100 \mathrm{mg} / \mathrm{L}) \text { of } \mathrm{NiO} \mathrm{NP} \\
\text { treatment. However, at higher treatment level }(>100 \\
\mathrm{mg} / \mathrm{L}) \text { of NiO NPs, concentrations of these metabolites } \\
\text { were reduced. }\end{array}$ & [151] \\
\hline $\begin{array}{c}\mathrm{CuO} \text { and } \\
\text { S-nitrosoglutathione } \\
(\mathrm{GSNO})\end{array}$ & Lactuca sativa & $\begin{array}{l}\text { Treatment resulted in positive effects on plant growth } \\
\text { and threefold increases in lettuce dry weight. Total } \\
\text { phenolic content (two-fold) and flavonoid content } \\
\text { (four-fold) were also increased significantly. Increased } \\
\text { accumulation of micronutrients such as } \mathrm{K}, \mathrm{Na}, \mathrm{Ca}, \mathrm{Mg} \text {, } \\
\text { and } \mathrm{S} \text { is observed in the leaves. }\end{array}$ & [152] \\
\hline
\end{tabular}


Table 4. Cont.

\begin{tabular}{|c|c|c|c|}
\hline Nanoparticles & Plant Name & Biochemical Changes/Significant Findings & References \\
\hline $\mathrm{Zn}$ & B. napus & $\begin{array}{l}\text { Many parameters such as protein, proline, total soluble } \\
\text { sugar (TSS), total flavonoid content (TFC), and total } \\
\text { phenolic content (TPC) were changed after NP } \\
\text { treatment. Activity of antioxidant enzymes such as } \\
\text { SOD, POD, and CAT also increased. }\end{array}$ & [153] \\
\hline $\mathrm{ZnO}$ & Vigna mungo & $\begin{array}{l}\text { Treatment was found to induce the activities of } \\
\text { antioxidant enzymes such as GPX, GR, and CAT and } \\
\text { was increase in the ascorbic acid and hydrogen } \\
\text { peroxide contents. }\end{array}$ & [154] \\
\hline $\begin{array}{c}\text { Combination of FeO } \\
\text { and hydrogel }\end{array}$ & Oryza sativa & $\begin{array}{l}\text { Treatment alleviated the } \mathrm{Cd} \text { and drought stress in rice } \\
\text { plants. Rice plants were found to have increased } \\
\text { biomass, increased activity of antioxidant enzymes } \\
\text { (SOD, POD, and CAT), and increased photosynthetic } \\
\text { efficiency, together with a reduction in ROS. }\end{array}$ & {$[60]$} \\
\hline
\end{tabular}

\section{Conclusions and Perspectives}

It is demonstrated that NPs can act as a potential stimulating agent, especially for germination, growth, and yield of various plants. Additionally, their applications can protect plants from detrimental consequences induced by numerous abiotic stresses because NPs display a moderately wide spectrum of actions (increase in water uptake into seeds, metabolism of starch reserves, stimulation of photosynthesis, changes in phytohormone levels, modulation of oxidative stress, or influenced uptake of nutrients) [65,155]. However, the majority of the studies have been conducted to understand one or other types of stress conditions. Future studies need to focus on more realistic stress condition in a practical scenario. The beneficial role of NPs on plant health has been proven by many studies; however, the exact understanding of the molecular mechanism behind the increased tolerance of plants is not clearly understood yet. Therefore, more investigation is required to understand how the NPs influence the antioxidant system of the plant cell, leading to increased tolerance to various kinds of stress. Such an understanding may help in designing smart NPs of the future that can help in mitigating stress and can ensure sustainable agriculture production.

Future studies need to focus on the interaction of NPs with signaling mechanisms leading to a change in gene expression of defense enzymes. In addition to that, currently, there are some limitations in using expensive NPs for agriculture. Treatment with gold and silver NPs is not economically feasible. Therefore, understanding the mechanism behind the workings of these NPs in modulating plant immunity may help in exploring an alternative method of increasing plant tolerance. The field application of many of the fabricated NPs is still very much limited because of changing environmental conditions, soil types, plants to be treated, and most importantly the physicochemical nature of metallic/non-metallic NPs. The constraints associated with field applications include the toxicity and accumulation of NPs in crop plants. Future studies pertaining to the appraisal of toxicological effects on model microbes, flora, and fauna are crucial to implementing nanotechnology for field application.

Several studies have envisaged the beneficial roles of NPs in the amelioration of salinity, heavy metal, and drought stresses. Nevertheless, the synergistic effect of the different treatments still needs further investigations to make concrete conclusions. Moreover, long-term studies on cereal crops and other strategic crops are suggested to demonstrate the relationship between NPs dose, soil types, and ecological impacts. Caution is necessary when evaluating the toxicological impact of NPs on different organisms and environments before utilizing their potential benefits. 
Author Contributions: Conceptualization and methodology, V.D.R., T.M., A.K., V.K.S., and H.; data curation, V.D.R. and A.K., writing-original draft, V.D.R., A.K., V.K.S., and H.; writing-review and editing, V.D.R., T.M., A.K., V.K.S., H., K.K.V., S.S. (Svetlana Sushkova)., S.M., S.S. (Sudhakar Srivastava), and C.K. All authors have read and agreed to the published version of the manuscript.

Funding: This research was supported by the Russian Foundation for Basic Research, projects no. 19-05-50097.

Institutional Review Board Statement: Not applicable.

Informed Consent Statement: Not applicable.

Acknowledgments: This research was supported by the Russian Foundation for Basic Research, projects no. 19-05-50097.

Conflicts of Interest: The authors declare that there are no competing interests.

\section{References}

1. Calicioglu, O.; Flammini, A.; Bracco, S.; Bellù, L.; Sims, R. The Future Challenges of Food and Agriculture: An Integrated Analysis of Trends and Solutions. Sustainability 2019, 11, 222. [CrossRef]

2. Ashraf, S.A.; Siddiqui, A.J.; Elkhalifa, A.E.O.; Khan, M.I.; Patel, M.; Alreshidi, M.; Moin, A.; Singh, R.; Snoussi, M.; Adnan, M. Innovations in Nanoscience dor the Sustainable Development of Food and Agriculture with Implications on Health and Environment. Sci. Total Environ. 2021, 768, 144990. [CrossRef]

3. Seleiman, M.F.; Almutairi, K.F.; Alotaibi, M.; Shami, A.; Alhammad, B.A.; Battaglia, M.L. Nano-Fertilization as an Emerging Fertilization Technique: Why Can Modern Agriculture Benefit from Its Use? Plants 2020, 10, 2. [CrossRef] [PubMed]

4. Ranjan, A.; Rajput, V.D.; Minkina, T.; Bauer, T.; Chauhan, A.; Jindal, T. Nanoparticles Induced Stress and Toxicity in Plants. Environ. Nanotechnol. Monit. Manag. 2021, 15, 100457. [CrossRef]

5. Haider, F.U.; Liqun, C.; Coulter, J.A.; Alam Cheema, S.; Wu, J.; Zhang, R.; Wenjun, M.; Farooq, M. Cadmium Toxicity in Plants: Impacts and Remediation Strategies. Ecotoxicol. Environ. Saf. 2021, 211, 111887. [CrossRef] [PubMed]

6. Godoy, F.; Olivos-Hernández, K.; Stange, C.; Handford, M. Abiotic Stress in Crop Species: Improving Tolerance by Applying Plant Metabolites. Plants 2021, 10, 186. [CrossRef] [PubMed]

7. Yadav, B.; Jogawat, A.; Rahman, S.; Narayan, O.P. Secondary Metabolites in the Drought Stress Tolerance of Crop Plants: A Review. Gene Rep. 2021, 23, 101040. [CrossRef]

8. $\quad$ Rajput, V.; Harish; Singh, R.; Verma, K.; Sharma, L.; Quiroz-Figueroa, F.; Meena, M.; Gour, V.; Minkina, T.; Sushkova, S.; et al. Recent Developments in Enzymatic Antioxidant Defence Mechanism in Plants with Special Reference to Abiotic Stress. Biology 2021, 10, 267. [CrossRef]

9. Rajput, V.; Minkina, T.; Semenkov, I.; Klink, G.; Tarigholizadeh, S.; Sushkova, S. Phylogenetic Analysis of Hyperaccumulator Plant Species for Heavy Metals and Polycyclic Aromatic Hydrocarbons. Environ. Geochem. Health 2021, 43, 1629-1654. [CrossRef]

10. Minkina, T.; Rajput, V.; Fedorenko, G.; Fedorenko, A.; Mandzhieva, S.; Sushkova, S.; Morin, T.; Yao, J. Anatomical and Ultrastructural Responses of Hordeum Sativum to the Soil Spiked by Copper. Environ. Geochem. Health 2020, 42, 45-58. [CrossRef]

11. Verma, K.K.; Anas, M.; Chen, Z.; Rajput, V.D.; Malviya, M.K.; Verma, C.L.; Singh, R.K.; Singh, P.; Song, X.-P.; Li, Y.-R. Silicon Supply Improves Leaf Gas Exchange, Antioxidant Defense System and Growth in Saccharum officinarum Responsive to Water Limitation. Plants 2020, 9, 1032. [CrossRef]

12. Ayup, M.; Chen, Y.-N.; Nyongesah, M.J.; Zhang, Y.-M.; Rajput, V.D.; Zhu, C.-G. Xylem Anatomy and Hydraulic Traits of Two Co-Occurring Riparian Desert Plants. IAWA J. 2015, 36, 69-83. [CrossRef]

13. Zulkafflee, N.S.; Redzuan, N.A.M.; Selamat, J.; Ismail, M.R.; Praveena, S.M.; Razis, A.F.A. Evaluation of Heavy Metal Contamination in Paddy Plants at the Northern Region of Malaysia Using ICPMS and Its Risk Assessment. Plants 2020, 10, 3. [CrossRef]

14. Li, Q.; Li, C.; Wang, H.; Wei, X.; Liu, Y.; Yang, R.; Wen, X. Geochemical Characteristics of Heavy Metals in Soil and Blueberries of the Core Majiang Blueberry Production Area. Bull. Environ. Contam. Toxicol. 2021, 106, 57-64. [CrossRef] [PubMed]

15. Rajput, V.; Minkina, T.; Mazarji, M.; Shende, S.; Sushkova, S.; Mandzhieva, S.; Burachevskaya, M.; Chaplygin, V.; Singh, A.; Jatav, H. Accumulation of Nanoparticles in the Soil-plant Systems and Their Sffects on Human Health. Ann. Agric. Sci. 2020, 65, 137-143. [CrossRef]

16. Chaplygin, V.A.; Rajput, V.D.; Mandzhieva, S.S.; Minkina, T.M.; Nevidomskaya, D.G.; Nazarenko, O.G.; Kalinitchenko, V.P.; Singh, R.; Maksimov, A.Y.; Popova, V.A. Comparison of Heavy Metal Content in Artemisia austriaca in Various Impact Zones. ACS Omega 2020, 5, 23393-23400. [CrossRef] [PubMed]

17. Malar, S.; Manikandan, R.; Favas, P.J.; Sahi, S.V.; Venkatachalam, P. Effect of Lead on Phytotoxicity, Growth, Biochemical Alterations and Its Role on Genomic Template Stability in Sesbania grandiflora: A Potential Plant for Phytoremediation. Ecotoxicol. Environ. Saf. 2014, 108, 249-257. [CrossRef] [PubMed] 
18. Fatemi, H.; Pour, B.E.; Rizwan, M. Foliar Application of Silicon Nanoparticles Affected the Growth, Vitamin C, Flavonoid, and Antioxidant Enzyme Activities of Coriander (Coriandrum sativum L.) Plants Grown in Lead (Pb)-Spiked Soil. Environ. Sci. Pollut. Res. 2021, 28, 1417-1425. [CrossRef]

19. Bidi, H.; Fallah, H.; Niknejad, Y.; Tari, D.B. Iron Oxide Nanoparticles Alleviate Arsenic Phytotoxicity In Rice by Improving Iron Uptake, Oxidative Stress Tolerance and Diminishing Arsenic Accumulation. Plant Physiol. Biochem. 2021, 163, 348-357. [CrossRef]

20. Kamran, M.; Parveen, A.; Ahmar, S.; Malik, Z.; Hussain, S.; Chattha, M.S.; Saleem, M.H.; Adil, M.; Heidari, P.; Chen, J.-T. An Overview of Hazardous Impacts of Soil Salinity in Crops, Tolerance Mechanisms, and Amelioration through Selenium Supplementation. Int. J. Mol. Sci. 2019, 21, 148. [CrossRef]

21. Zia, R.; Nawaz, M.S.; Siddique, M.J.; Hakim, S.; Imran, A. Plant Survival Under Drought Stress: Implications, Adaptive Responses, and Integrated Rhizosphere Management Strategy for Stress Mitigation. Microbiol. Res. 2021, 242, 126626. [CrossRef]

22. Rajput, V.D.; Yaning, C.; Ayup, M.; Minkina, T.; Sushkova, S.; Mandzhieva, S. Physiological and Hydrological Changes in Populus euphratica Seedlings Under Salinity Stress. Acta Ecol. Sin. 2017, 37, 229-235. [CrossRef]

23. Shahid, M.A.; Sarkhosh, A.; Khan, N.; Balal, R.M.; Ali, S.; Rossi, L.; Gómez, C.; Mattson, N.; Nasim, W.; Garcia-Sanchez, F. Insights into the Physiological and Biochemical Impacts of Salt Stress on Plant Growth and Development. Agronomy 2020, 10, 938. [CrossRef]

24. Rajput, V.D.; Minkina, T.; Yaning, C.; Sushkova, S.; Chapligin, V.A.; Mandzhieva, S. A Review on Salinity Adaptation Mechanism and Characteristics of Populus euphratica, A Boon for Arid Ecosystems. Acta Ecol. Sin. 2016, 36, 497-503. [CrossRef]

25. Ibrahim, W.; Zhu, Y.-M.; Chen, Y.; Qiu, C.-W.; Zhu, S.; Wu, F.; Shuijin, Z. Genotypic Differences in Leaf Secondary Metabolism, Plant Hormones and Yield Under Alone and Combined Stress of Drought and Salinity In Cotton Genotypes. Physiol. Plant 2018, 165, 343-355. [CrossRef]

26. Rajput, V.; Minkina, T.; Ahmed, B.; Sushkova, S.; Singh, R.; Soldatov, M.; Laratte, B.; Fedorenko, A.; Mandzhieva, S.; Blicharska, E.; et al. Interaction of Copper-Based Nanoparticles to Soil, Terrestrial, and Aquatic Systems: Critical Review of the State of the Science and Future Perspectives. In Reviews of Environmental Contamination and Toxicology; de Voogt, P., Ed.; Springer: Cham, Switzerland, 2019; Volume 250, pp. 51-96.

27. Pelegrino, M.T.; Kohatsu, M.Y.; Seabra, A.B.; Monteiro, L.R.; Gomes, D.G.; Oliveira, H.C.; Rolim, W.R.; De Jesus, T.A.; Batista, B.L.; Lange, C.N. Effects of Copper Oxide Nanoparticles on Growth of Lettuce (Lactuca sativa L.) Seedlings and Possible Implications of Nitric Oxide in Their Antioxidative Defense. Environ. Monit. Assess. 2020, 192, 1-14. [CrossRef]

28. Rajput, V.; Chaplygin, V.; Gorovtsov, A.; Fedorenko, A.; Azarov, A.; Chernikova, N.; Barakhov, A.; Minkina, T.; Maksimov, A.; Mandzhieva, S.; et al. Assessing the Toxicity and Accumulation of Bulk- and Nano-Cuo in Hordeum sativum L. Environ. Geochem. Health 2020, 43, 2443-2454. [CrossRef]

29. Youssef, M.S.; Elamawi, R. Evaluation of Phytotoxicity, Cytotoxicity, and Genotoxicity of ZnO Nanoparticles in Vicia faba. Environ. Sci. Pollut. Res. 2018, 27, 18972-18984. [CrossRef]

30. Adrees, M.; Khan, Z.S.; Ali, S.; Hafeez, M.; Khalid, S.; Rehman, M.Z.U.; Hussain, A.; Hussain, K.; Chatha, S.A.S.; Rizwan, M. Simultaneous Mitigation of Cadmium and Drought Stress in Wheat by Soil Application of Iron Nanoparticles. Chemosphere 2020, 238, 124681. [CrossRef] [PubMed]

31. Kolesnikov, S.; Tsepina, N.; Minnikova, T.; Kazeev, K.; Mandzhieva, S.; Sushkova, S.; Minkina, T.; Mazarji, M.; Singh, R.; Rajput, V. Influence of Silver Nanoparticles on the Biological Indicators of Haplic Chernozem. Plants 2021, 10, 1022. [CrossRef]

32. Arya, A.; Mishra, V.; Chundawat, T.S. Green Synthesis of Silver Nanoparticles from Green Algae (Botryococcus braunii) and Its Catalytic Behavior for the Synthesis of Benzimidazoles. Chem. Data Collect. 2019, 20, 100190. [CrossRef]

33. Staron, A.; Długosz, O.; Pulit-Prociak, J.; Banach, M. Analysis of the Exposure of Organisms to the Action of Nanomaterials. Materials 2020, 13, 349. [CrossRef]

34. Verma, S.K.; Das, A.K.; Gantait, S.; Kumar, V.; Gurel, E. Applications of Carbon Nanomaterials in the Plant System: A Perspective View on the Pros and Cons. Sci. Total Environ. 2019, 667, 485-499. [CrossRef]

35. Liu, R.; Lal, R. Potentials of Engineered Nanoparticles as Fertilizers for Increasing Agronomic Productions. Sci. Total Environ. 2015, 514, 131-139. [CrossRef] [PubMed]

36. Wang, P.; Lombi, E.; Zhao, F.-J.; Kopittke, P.M. Nanotechnology: A New Opportunity in Plant Sciences. Trends Plant Sci. 2016, 21, 699-712. [CrossRef] [PubMed]

37. Sebastian, A.; Nangia, A.; Prasad, M. A Green Synthetic Route to Phenolics Fabricated Magnetite Nanoparticles From Coconut Husk Extract: Implications to Treat Metal Contaminated Water and Heavy Metal Stress in Oryza sativa L. J. Clean. Prod. 2018, 174, 355-366. [CrossRef]

38. Ali, S.; Rizwan, M.; Hussain, A.; Rehman, M.Z.U.; Ali, B.; Yousaf, B.; Wijaya, L.; Alyemeni, M.N.; Ahmad, P. Silicon Nanoparticles Enhanced the Growth and Reduced the Cadmium Accumulation in Grains of Wheat (Triticum aestivum L.). Plant Physiol. Biochem. 2019, 140, 1-8. [CrossRef]

39. Singh, D.; Singh, S.K.; Singh, V.K.; Verma, H.; Mishra, M.; Rashmi, K.; Kumar, A. Plant Growth-promoting Bacteria: Application in Bioremediation of Salinity and Heavy Metal-Contaminated Soils. In Microbe Mediated Remediation of Environmental Contaminants; Kumar, A., Singh, V.K., Singh, P., Mishra, V.K., Eds.; Woodhead Publishing: Sawston, UK, 2021; pp. 73-78.

40. Tombuloglu, H.; Slimani, Y.; Tombuloglu, G.; Alshammari, T.; Almessiere, M.; Korkmaz, A.D.; Baykal, A.; Samia, A.C.S. Engineered Magnetic Nanoparticles Enhance Chlorophyll Content and Growth of Barley Through the Induction of Photosystem Genes. Environ. Sci. Pollut. Res. 2020, 27, 34311-34321. [CrossRef] 
41. Ali, E.; El-Shehawi, A.; Ibrahim, O.; Abdul-Hafeez, E.; Moussa, M.; Hassan, F. A Vital Role of Chitosan Nanoparticles in Improvisation the Drought Stress Tolerance in Catharanthus roseus (L.) Through Biochemical and Gene Expression Modulation. Plant Physiol. Biochem. 2021, 161, 166-175. [CrossRef]

42. Singh, D.; Sillu, D.; Kumar, A.; Agnihotri, S. Dual Nanozyme Characteristics of Iron Oxide Nanoparticles Alleviate Salinity Stress and Promote the Growth of An Agroforestry Tree, Eucalyptus tereticornis Sm. Environ. Sci. Nano 2021, 8, 1308-1325. [CrossRef]

43. Chaplygin, V.; Mandzhieva, S.; Minkina, T.; Barahov, A.; Nevidomskaya, D.; Kizilkaya, R.; GULSER, C.; Chernikova, N.; Mazarji, M.; Iljina, L.; et al. Accumulating Capacity of Herbaceous Plants of the Asteraceae and Poaceae Families Under Technogenic Soil Pollution with Zinc and Cadmium. Eeurasian J. Soil Sci. 2020, 9, 165-172. [CrossRef]

44. Ghazaryan, K.; Movsesyan, H.; Gevorgyan, A.; Minkina, T.; Sushkova, S.; Rajput, V.; Mandzhieva, S. Comparative Hydrochemical Assessment of Groundwater Quality from Different Aquifers for Irrigation Purposes Using IWQI: A Case-Study from Masis Province in Armenia. Groundw. Sustain. Dev. 2020, 11, 100459. [CrossRef]

45. Ennaji, W.; Barakat, A.; El Baghdadi, M.; Rais, J. Heavy Metal Contamination in Agricultural Soil and Ecological Risk Assessment in The Northeast Area of Tadla Plain, Morocco. J. Sediment. Environ. 2020, 5, 307-320. [CrossRef]

46. Zamora-Ledezma, C.; Negrete-Bolagay, D.; Figueroa, F.; Zamora-Ledezma, E.; Ni, M.; Alexis, F.; Guerrero, V.H. Heavy Metal Water Pollution: A Fresh Look About Hazards, Novel and Conventional Remediation Methods. Environ. Technol. Innov. 2021, 22, 101504. [CrossRef]

47. Galati, S.; Gullì, M.; Giannelli, G.; Furini, A.; DalCorso, G.; Fragni, R.; Buschini, A.; Visioli, G. Heavy Metals Modulate DNA Compaction and Methylation at CpG Sites in the Metal Hyperaccumulator Arabidopsis halleri. Environ. Mol. Mutagen. 2021, 62, 133-142. [CrossRef]

48. Kontaş, S.; Bostanc1, D. Genotoxic Effects of Environmental Pollutant Heavy Metals on Alburnus chalcoides (Pisces: Cyprinidae) Inhabiting Lower Melet River (Ordu, Turkey). Bull. Environ. Contam. Toxicol. 2020, 104, 763-769. [CrossRef] [PubMed]

49. Sall, M.L.; Diaw, A.K.D.; Gningue-Sall, D.; Aaron, S.E.; Aaron, J.-J. Toxic Heavy Metals: Impact on the Environment and Human Health, and Treatment with Conducting Organic Polymers, A Review. Environ. Sci. Pollut. Res. 2020, 27, 29927-29942. [CrossRef]

50. Raja, V.; Lakshmi, R.V.; Sekar, C.P.; Chidambaram, S.; Neelakantan, M.A. Health Risk Assessment of Heavy Metals in Groundwater of Industrial Township Virudhunagar, Tamil Nadu, India. Arch. Environ. Contam. Toxicol. 2021, 80, 144-163. [CrossRef]

51. Zhao, Q.; Bai, J.; Gao, Y.; Zhang, G.; Lu, Q.; Jia, J. Heavy Metal Contamination in Soils from Freshwater Wetlands to Salt Marshes in the Yellow River Estuary, China. Sci. Total Environ. 2021, 774, 145072. [CrossRef]

52. Alaboudi, K.A.; Ahmed, B.; Brodie, G. Phytoremediation of Pb and Cd Contaminated Soils by Using Sunflower (Helianthus annuus) Plant. Ann. Agric. Sci. 2018, 63, 123-127. [CrossRef]

53. Shah, T.; Latif, S.; Saeed, F.; Ali, I.; Ullah, S.; Abdullah Alsahli, A.; Jan, S.; Ahmad, P. Seed Priming with Titanium Dioxide Nanoparticles Enhances Seed Vigor, Leaf Water Status, and Antioxidant Enzyme Activities in Maize (Zea mays L.) under salinity stress. J. King Saud. Univ. Sci. 2021, 33, 101207. [CrossRef]

54. Shah, V.; Daverey, A. Effects of Sophorolipids Augmentation on the Plant Growth and Phytoremediation of Heavy Metal Contaminated Soil. J. Clean. Prod. 2021, 280, 124406. [CrossRef]

55. Chen, S.; Chen, L.; Ma, Y.; Huang, Y. Can Phosphate Compounds be Used to Reduce the Plant Uptake of Pb and Resist the Pb Stress in Pb-Contaminated Soils? J. Environ. Sci. 2009, 21, 360-365. [CrossRef]

56. Wang, M.; Chen, L.; Chen, S.; Ma, Y. Alleviation of Cadmium-Induced Root Growth Inhibition in Crop Seedlings by Nanoparticles. Ecotoxicol. Environ. Saf. 2012, 79, 48-54. [CrossRef] [PubMed]

57. Noman, M.; Shahid, M.; Ahmed, T.; Tahir, M.; Naqqash, T.; Muhammad, S.; Song, F.; Abid, H.M.A.; Aslam, Z. Green Copper Nanoparticles drom A Native Klebsiella Pneumoniae Strain Alleviated Oxidative Stress Impairment of Wheat Plants by Reducing the Chromium Bioavailability and Increasing the Growth. Ecotoxicol. Environ. Saf. 2020, 192, 110303. [CrossRef] [PubMed]

58. Noman, M.; Ahmed, T.; Hussain, S.; Niazi, M.B.K.; Shahid, M.; Song, F. Biogenic Copper Nanoparticles Synthesized by Using a Copper-Resistant Strain Shigella Flexneri Snt22 Reduced the Translocation of Cadmium from Soil to Wheat Plants. J. Hazard. Mater. 2020, 398, 123175. [CrossRef]

59. Ahmed, T.; Noman, M.; Manzoor, N.; Shahid, M.; Abdullah, M.; Ali, L.; Wang, G.; Hashem, A.; Al-Arjani, A.-B.F.; Alqarawi, A.A.; et al. Nanoparticle-Based Amelioration of Drought Stress and Cadmium Toxicity in Rice via Triggering the Stress Responsive Genetic Mechanisms and Nutrient Acquisition. Ecotoxicol. Environ. Saf. 2021, 209, 111829. [CrossRef]

60. Manzoor, N.; Ahmed, T.; Noman, M.; Shahid, M.; Nazir, M.M.; Ali, L.; Alnusaire, T.S.; Li, B.; Schulin, R.; Wang, G. Iron Oxide Nanoparticles Ameliorated the Cadmium and Salinity Stresses in Wheat Plants, Facilitating Photosynthetic Pigments and Restricting Cadmium Uptake. Sci. Total Environ. 2021, 769, 145221. [CrossRef]

61. Zhou, P.; Adeel, M.; Shakoor, N.; Guo, M.; Hao, Y.; Azeem, I.; Li, M.; Liu, M.; Rui, Y. Application of Nanoparticles Alleviates Heavy Metals Stress and Promotes Plant Growth: An Overview. Nanomaterials 2020, 11, 26. [CrossRef]

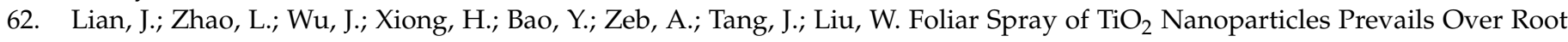
Application in Reducing Cd Accumulation and Mitigating Cd-Induced Phytotoxicity in Maize (Zea mays L.). Chemosphere 2020, 239, 124794. [CrossRef]

63. Li, Y.; Zhu, N.; Liang, X.; Bai, X.; Zheng, L.; Zhao, J.; Li, Y.-F.; Zhang, Z.; Gao, Y. Silica Nanoparticles Alleviate Mercury Toxicity via Immobilization and Inactivation of $\mathrm{Hg}(\mathrm{Ii})$ in Soybean (Glycine max). Environ. Sci. Nano 2020, 7, 1807-1817. [CrossRef]

64. Jiang, M.; Dai, S.; Wang, B.; Xie, Z.; Li, J.; Wang, L.; Li, S.; Tan, Y.; Tian, B.; Shu, Q.; et al. Gold Nanoparticles Synthesized Using Melatonin Suppress Cadmium Uptake and Alleviate Its Toxicity in Rice. Environ. Sci. Nano 2021, 8, 1042-1056. [CrossRef] 
65. Khan, Z.S.; Rizwan, M.; Hafeez, M.; Ali, S.; Adrees, M.; Qayyum, M.F.; Khalid, S.; Rehman, M.Z.U.; Sarwar, M.A. Effects of silicon nanoparticles on growth and physiology of wheat in cadmium contaminated soil under different soil moisture levels. Environ. Sci. Pollut. Res. 2020, 27, 4958-4968. [CrossRef] [PubMed]

66. Ahmad, P.; Alyemeni, M.N.; Al-Huqail, A.A.; Alqahtani, M.A.; Wijaya, L.; Ashraf, M.; Kaya, C.; Bajguz, A. Zinc Oxide Nanoparticles Application Alleviates Arsenic (As) Toxicity in Soybean Plants by Restricting the Uptake of as and Modulating Key Biochemical Attributes, Antioxidant Enzymes, Ascorbate-Glutathione Cycle and Glyoxalase System. Plants 2020, 9, 825. [CrossRef]

67. Katiyar, P.; Yadu, B.; Korram, J.; Satnami, M.L.; Kumar, M.; Keshavkant, S. Titanium Nanoparticles Attenuates Arsenic Toxicity by Up-Regulating Expressions of Defensive Genes in Vigna radiata L. J. Environ. Sci. 2020, 92, 18-27. [CrossRef]

68. Hussain, B.; Lin, Q.; Hamid, Y.; Sanaullah, M.; Di, L.; Hashmi, M.L.U.R.; Khan, M.B.; He, Z.; Yang, X. Foliage Application of Selenium and Silicon Nanoparticles Alleviates Cd And Pb Toxicity in Rice (Oryza sativa L.). Sci. Total Environ. 2020, $712,136497$. [CrossRef] [PubMed]

69. Tripathi, D.K.; Singh, V.P.; Prasad, S.M.; Chauhan, D.K.; Dubey, N.K. Silicon Nanoparticles (SiNP) Alleviate Chromium (VI) Phytotoxicity in Pisum sativum (L.) Seedlings. Plant Physiol. Biochem. 2015, 96, 189-198. [CrossRef]

70. Venkatachalam, P.; Jayaraj, M.; Manikandan, R.; Geetha, N.; Rene, E.R.; Sharma, N.; Sahi, S. Zinc Oxide Nanoparticles (ZnO NPS) Alleviate Heavy Metal-Induced Toxicity in Leucaena Leucocephala Seedlings: A Physiochemical Analysis. Plant Physiol. Biochem. 2017, 110, 59-69. [CrossRef]

71. Konate, A.; He, X.; Zhang, Z.; Ma, Y.; Zhang, P.; Alugongo, G.M.; Rui, Y. Magnetic (Fe3O4) Nanoparticles Reduce Heavy Metals Uptake and Mitigate Their Toxicity in Wheat Seedling. Sustainability 2017, 9, 790. [CrossRef]

72. Cui, J.; Liu, T.; Li, F.; Yi, J.; Liu, C.; Yu, H.-Y. Silica Nanoparticles Alleviate Cadmium Toxicity in Rice Cells: Mechanisms and Size Effects. Environ. Pollut. 2017, 228, 363-369. [CrossRef]

73. Rizwan, M.; Ali, S.; Zia Ur Rehman, M.Z.U.; Adrees, M.; Arshad, M.; Qayyum, M.F.; Ali, L.; Hussain, A.; Chatha, S.A.S.; Imran, M. Alleviation of Cadmium Accumulation in Maize (Zea mays L.) by Foliar Spray of Zinc Oxide Nanoparticles and Biochar to Contaminated Soil. Environ. Pollut. 2019, 248, 358-367. [CrossRef] [PubMed]

74. Rizwan, M.; Ali, S.; Ali, B.; Adrees, M.; Arshad, M.; Hussain, A.; Rehman, M.Z.U.; Waris, A.A. Zinc and Iron Oxide Nanoparticles Improved the Plant Growth and Reduced the Oxidative Stress and Cadmium Concentration in Wheat. Chemosphere 2019, 214, 269-277. [CrossRef] [PubMed]

75. Yan, S.; Wu, F.; Zhou, S.; Yang, J.; Tang, X.; Ye, W. Zinc Oxide Nanoparticles Alleviate the Arsenic Toxicity and Decrease the Accumulation of Arsenic in Rice (Oryza sativa L.). BMC Plant Biol. 2021, 21, 1-11. [CrossRef] [PubMed]

76. Islam, A.; Shelia, V.; Ludwig, F.; de Bruyn, L.L.; Rahman, M.H.U.; Hoogenboom, G. Bringing Farmers' Perceptions into Science and Policy: Understanding Salinity Tolerance of Rice in Southwestern Bangladesh Under Climate Change. Land Use Policy 2021, 101, 105159. [CrossRef]

77. Ahmad, I.; Akhtar, M.S. Use of Nanoparticles in Alleviating Salt Stress. In Salt Stress, Microbes, and Plant Interactions: Causes and Solution; Akhtar, M.S., Ed.; Springer: Singapore, 2019; Volume 1, pp. 199-215.

78. Khadka, K.; Earl, H.J.; Raizada, M.N.; Navabi, A. A Physio-Morphological Trait-Based Approach for Breeding Drought Tolerant Wheat. Front. Plant Sci. 2020, 11, 715. [CrossRef]

79. Kumar, A.; Singh, S.; Gaurav, A.K.; Srivastava, S.; Verma, J.P. Plant Growth-Promoting Bacteria: Biological Tools for the Mitigation of Salinity Stress in Plants. Front. Microbiol. 2020, 11, 1216. [CrossRef] [PubMed]

80. El-Saber, M.M.; A Mahdi, A.; Hassan, A.H.; Farroh, K.Y.; Osman, A. Effects of Magnetite Nanoparticles on Physiological Processes to Alleviate Salinity Induced Oxidative Damage in Wheat. J. Sci. Food Agric. 2021. [CrossRef] [PubMed]

81. Farhangi-Abriz, S.; Torabian, S. Nano-Silicon Alters Antioxidant Activities of Soybean Seedlings Under Salt Toxicity. Protoplasma 2018, 255, 953-962. [CrossRef]

82. Mushtaq, A.; Rizwan, S.; Jamil, N.; Ishtiaq, T.; Irfan, S.; Ismail, T.; Malghani, M.N.; Shahwani, M.N. Influence of Silicon Sources and Controlled Release Fertilizer on the Growth of Wheat Cultivars of Balochistan Under Salt Stress. Pak. J. Bot. 2019, 51, 1561-1567. [CrossRef]

83. Farouk, S.; Al-Amri, S.M. Exogenous Zinc Forms Counteract NaCl-Induced Damage by Regulating the Antioxidant System, Osmotic Adjustment Substances, and Ions in Canola (Brassica napus L. cv. Pactol) Plants. J. Soil Sci. Plant Nutr. 2019, 19, 887-899. [CrossRef]

84. Pérez-Labrada, F.; López-Vargas, E.R.; Ortega-Ortiz, H.; Cadenas-Pliego, G.; Benavides-Mendoza, A.; Juárez-Maldonado, A. Responses of Tomato Plants under Saline Stress to Foliar Application of Copper Nanoparticles. Plants 2019, 8, 151. [CrossRef]

85. Mohamed, A.K.S.H.; Qayyum, M.F.; Abdel-Hadi, A.; Rehman, R.A.; Ali, S.; Rizwan, M. Interactive Effect of Salinity and Silver Nanoparticles on Photosynthetic and Biochemical Parameters of Wheat. Arch. Agron. Soil Sci. 2017, 63, 1736-1747. [CrossRef]

86. Abdoli, S.; Ghassemi-Golezani, K.; Alizadeh-Salteh, S. Responses of Ajowan (Trachyspermum ammi L.) to Exogenous Salicylic Acid and Iron Oxide Nanoparticles under Salt Stress. Environ. Sci. Pollut. Res. 2020, 27, 36939-36953. [CrossRef] [PubMed]

87. Mahmoud, A.W.M.; Abdeldaym, E.A.; Abdelaziz, S.M.; El-Sawy, M.B.I.; Mottaleb, S.A. Synergetic Effects of Zinc, Boron, Silicon, and Zeolite Nanoparticles on Confer Tolerance in Potato Plants Subjected to Salinity. Agronomy 2019, 10, 19. [CrossRef]

88. Mozafari, A.-A.; Ghadakchi Asl, A.G.; Ghaderi, N. Grape Response to Salinity Stress and Role of Iron Nanoparticle and Potassium Silicate to Mitigate Salt Induced Damage Under in vitro Conditions. Physiol. Mol. Biol. Plants 2018, 24, 25-35. [CrossRef] [PubMed] 
89. Mozafari, A.A.; Dedejani, S.; Ghaderi, N. Positive Responses of Strawberry (Fragaria $\times$ ananassa Duch.) Explants to Salicylic and Iron Nanoparticle Application under Salinity Conditions. Plant Cell Tissue Organ Cult. 2018, 134, 267-275. [CrossRef]

90. Kafi, M.; Nabati, J.; Saadatian, B.; Oskoueian, A.; Shabahang, J. Potato Response to Silicone Compounds (Micro and Nanoparticles) and Potassium as Affected by Salinity Stress. Ital. J. Agron. 2019, 14, 162-169. [CrossRef]

91. Mahmoud, L.M.; Dutt, M.; Shalan, A.M.; El-Kady, M.E.; El-Boray, M.S.; Shabana, Y.; Grosser, J.W. Silicon Nanoparticles Mitigate Oxidative Stress of in vitro-Derived Banana (Musa acuminata 'Grand Nain') under Simulated Water Deficit or Salinity Stress. S. Afr. J. Bot. 2020, 132, 155-163. [CrossRef]

92. Baz, H.; Creech, M.; Chen, J.; Gong, H.; Bradford, K.; Huo, H. Water-Soluble Carbon Nanoparticles Improve Seed Germination and Post-Germination Growth of Lettuce under Salinity Stress. Agronomy 2020, 10, 1192. [CrossRef]

93. Noohpisheh, Z.; Amiri, H.; Mohammadi, A.; Farhadi, S. Effect of the Foliar Application of Zinc Oxide Nanoparticles on Some Biochemical and Physiological Parameters of Trigonella foenum-graecum under Salinity Stress. Plant Biosyst. Int. J. Deal. Asp. Plant Biol. 2021, 155, 267-280. [CrossRef]

94. Faizan, M.; Bhat, J.A.; Chen, C.; Alyemeni, M.N.; Wijaya, L.; Ahmad, P.; Yu, F. Zinc Oxide Nanoparticles (Zno-NPs) Induce Salt Tolerance by Improving the Antioxidant System and Photosynthetic Machinery in Tomato. Plant Physiol. Biochem. 2021, 161, 122-130. [CrossRef]

95. Kumari, A.; Kaur, R.; Kaur, R. An Insight into Drought Stress and Signal Transduction of Abscisic Acid. Plant Sci. Today 2018, 5 , 72-80. [CrossRef]

96. Wang, R.-K.; Li, L.-L.; Cao, Z.-H.; Zhao, Q.; Li, M.; Zhang, L.-Y.; Hao, Y.-J. Molecular Cloning and Functional Characterization of a Novel Apple Mdcipk6l Gene Reveals Its Involvement in Multiple Abiotic Stress Tolerance in Transgenic Plants. Plant Mol. Biol. 2012, 79, 123-135. [CrossRef]

97. Chandra, P.; Wunnava, A.; Verma, P.; Chandra, A.; Sharma, R.K. Strategies to Mitigate the Adverse Effect of Drought Stress on Crop Plants-Influences of Soil Bacteria: A Review. Pedosphere 2021, 31, 496-509. [CrossRef]

98. Sanjari, S.; Shobbar, Z.-S.; Ghanati, F.; Afshari-Behbahanizadeh, S.; Farajpour, M.; Jokar, M.; Khazaei, A.; Shahbazi, M. Molecular, Chemical, and Physiological Analyses of Sorghum Leaf Wax under Post-Flowering Drought Stress. Plant Physiol. Biochem. 2021, 159, 383-391. [CrossRef]

99. Farooq, M.; Wahid, A.; Kobayashi, N.; Fujita, D.; Basra, S.M.A. Plant Drought Stress: Effects, Mechanisms and Management. Agron. Sustain. Dev. 2009, 29, 185-212. [CrossRef]

100. Hu, Y.; Schmidhalter, U. Drought and Salinity: A Comparison of Their Effects on Mineral Nutrition of Plants. J. Plant Nutr. Soil Sci. 2005, 168, 541-549. [CrossRef]

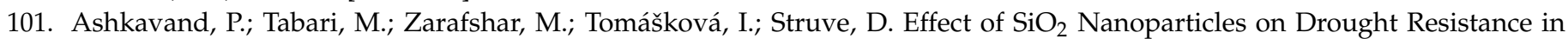
Hawthorn Seedlings. For. Res. Pap. 2015, 76, 350-359. [CrossRef]

102. Aghdam, M.T.B.; Mohammadi, H.; Ghorbanpour, M. Effects of Nanoparticulate Anatase Titanium Dioxide on Physiological and Biochemical Performance of Linum usitatissimum (Linaceae) under Well-Watered and Drought Stress Conditions. Braz. J. Bot. 2016, 39, 139-146. [CrossRef]

103. Kamalizadeh, M.; Bihamta, M.; Zarei, A. Drought Stress and $\mathrm{TiO}_{2}$ Nanoparticles Affect the Composition of Different Active Compounds in the Moldavian Dragonhead Plant. Acta Physiol. Plant 2019, 41, 21. [CrossRef]

104. Dimkpa, C.O.; Andrews, J.; Fugice, J.; Singh, U.; Bindraban, P.S.; Elmer, W.H.; Gardea-Torresdey, J.L.; White, J.C. Facile Coating of Urea with Low-Dose ZnO Nanoparticles Promotes Wheat Performance and Enhances Zn Uptake Under Drought Stress. Front. Plant Sci. 2020, 11, 168. [CrossRef] [PubMed]

105. Zahedi, S.M.; Moharrami, F.; Sarikhani, S.; Padervand, M. Selenium and Silica Nanostructure-Based Recovery of Strawberry Plants Subjected to Drought Stress. Sci. Rep. 2020, 10, 1-18. [CrossRef]

106. Nguyen, D.V.; Nguyen, H.M.; Le, N.T.; Nguyen, K.H.; Nguyen, H.T.; Le, H.M.; Nguyen, A.T.; Dinh, N.T.T.; Hoang, S.A.; Ha, C.V. Copper Nanoparticle Application Enhances Plant Growth and Grain Yield in Maize Under Drought Stress Conditions. J. Plant Growth Regul. 2021, 1-12. [CrossRef]

107. Semida, W.M.; Abdelkhalik, A.; Mohamed, G.F.; Abd El-Mageed, T.A.; Abd El-Mageed, S.A.; Rady, M.M.; Ali, E.F. Foliar Application of Zinc Oxide Nanoparticles Promotes Drought Stress Tolerance in Eggplant (Solanum melongena L.). Plants 2021, 10, 421. [CrossRef] [PubMed]

108. Behboudi, F.; Tahmasebi-Sarvestani, Z.; Kassaee, M.Z.; Modarres-Sanavy, S.A.M.; Sorooshzadeh, A.; Mokhtassi-Bidgoli, A. Evaluation of Chitosan Nanoparticles Effects with Two Application Methods on Wheat under Drought Stress. J. Plant Nutr. 2019, 42, 1439-1451. [CrossRef]

109. Elsheery, N.I.; Helaly, M.N.; El-Hoseiny, H.M.; Alam-Eldein, S.M. Zinc Oxide and Silicone Nanoparticles to Improve the Resistance Mechanism and Annual Productivity of Salt-Stressed Mango Trees. Agronomy 2020, 10, 558. [CrossRef]

110. Adrees, M.; Khan, Z.S.; Hafeez, M.; Rizwan, M.; Hussain, K.; Asrar, M.; Alyemeni, M.N.; Wijaya, L.; Ali, S. Foliar Exposure of Zinc Oxide Nanoparticles Improved the Growth of Wheat (Triticum aestivum L.) and Decreased Cadmium Concentration in Grains under Simultaneous Cd and Water Deficient Stress. Ecotoxicol. Environ. Saf. 2021, 208, 111627. [CrossRef]

111. Mosa, K.A.; El-Naggar, M.; Ramamoorthy, K.; Alawadhi, H.; Elnaggar, A.; Wartanian, S.; Ibrahim, E.; Hani, H. Copper Nanoparticles Induced Genotoxicty, Oxidative Stress, and Changes in Superoxide Dismutase (SOD) Gene Expression in Cucumber (Cucumis sativus) Plants. Front. Plant Sci. 2018, 9, 872. [CrossRef] 
112. Burman, U.; Saini, M.; Kumar, P.-. Effect of Zinc Oxide Nanoparticles on Growth and Antioxidant System of Chickpea Seedlings. Toxicol. Environ. Chem. 2013, 95, 605-612. [CrossRef]

113. Singh, N.B.; Amist, N.; Yadav, K.; Singh, D.; Pandey, J.K.; Singh, S.C. Zinc Oxide Nanoparticles as Fertilizer for the Germination, Growth and Metabolism of Vegetable Crops. J. Nanoeng. Nanomanuf. 2013, 3, 353-364. [CrossRef]

114. Hernández-Hernández, H.; Quiterio-Gutiérrez, T.; Cadenas-Pliego, G.; Ortega-Ortiz, H.; Hernández-Fuentes, A.D.; Cabrera De La Fuente, M.C.; Valdés-Reyna, J.; Juárez-Maldonado, A. Impact of Selenium and Copper Nanoparticles on Yield, Antioxidant System, and Fruit Quality of Tomato Plants. Plants 2019, 8, 355. [CrossRef]

115. Choudhary, R.C.; Kumaraswamy, R.V.; Kumari, S.; Sharma, S.S.; Pal, A.; Raliya, R.; Biswas, P.; Saharan, V. Cu-chitosan Nanoparticle Boost Defense Responses and Plant Growth in Maize (Zea mays L.). Sci. Rep. 2017, 7, 1-11. [CrossRef] [PubMed]

116. Venkatachalam, P.; Priyanka, N.; Manikandan, K.; Ganeshbabu, I.; Indiraarulselvi, P.; Geetha, N.; Muralikrishna, K.; Bhattacharya, R.C.; Tiwari, M.; Sharma, N.; et al. Enhanced Plant Growth Promoting Role of Phycomolecules Coated Zinc Oxide Nanoparticles with P Supplementation in Cotton (Gossypium hirsutum L.). Plant Physiol. Biochem. 2017, 110, 118-127. [CrossRef]

117. Priyanka, N.; Venkatachalam, P. Biofabricated Zinc Oxide Nanoparticles Coated with Phycomolecules as Novel Micronutrient Catalysts for Stimulating Plant Growth of Cotton. Adv. Nat. Sci. Nanosci. Nanotechnol. 2016, 7, 045018. [CrossRef]

118. Ghorbanpour, M.; Hatami, M.; Hatami, M. Activating Antioxidant Enzymes, Hyoscyamine and Scopolamine Biosynthesis of Hyoscyamus niger 1. Plants with Nano-sized Titanium Dioxide and Bulk Application. Acta Agric. Slov. 2015, 105, 23-32. [CrossRef]

119. Faizan, M.; Faraz, A.; Yusuf, M.; Khan, S.T.; Hayat, S. Zinc Oxide Nanoparticle-Mediated Changes in Photosynthetic Efficiency and Antioxidant System of Tomato Plants. Photosynthesis 2018, 56, 678-686. [CrossRef]

120. de Sousa, A.; Saleh, A.M.; Habeeb, T.H.; Hassan, Y.M.; Zrieq, R.; Wadaan, M.A.; Hozzein, W.N.; Selim, S.; Matos, M.; AbdElgawad, H. Silicon Dioxide Nanoparticles Ameliorate the Phytotoxic Hazards of Aluminum in Maize Grown on Acidic Soil. Sci. Total Environ. 2019, 693, 133636. [CrossRef] [PubMed]

121. Moradbeygi, H.; Jamei, R.; Heidari, R.; Darvishzadeh, R. Investigating the Enzymatic and Non-Enzymatic Antioxidant Defense by Applying Iron Oxide Nanoparticles in Dracocephalum moldavica L. Plant under Salinity Stress. Sci. Hortic. 2020, $272,109537$. [CrossRef]

122. Farhangi-Abriz, S.; Ghassemi-Golezani, K. Changes in Soil Properties and Salt Tolerance of Safflower in Response to Biochar-Based Metal Oxide Nanocomposites of Magnesium and Manganese. Ecotoxicol. Environ. Saf. 2021, 211, 111904. [CrossRef]

123. Rivero-Montejo, S.; Vargas-Hernandez, M.; Torres-Pacheco, I. Nanoparticles as Novel Elicitors to Improve Bioactive Compounds in Plants. Agriculture 2021, 11, 134. [CrossRef]

124. Wang, J.; Mei, J.; Ren, G. Plant microRNAs: Biogenesis, Homeostasis, and Degradation. Front. Plant Sci. 2019, 10, 360. [CrossRef] [PubMed]

125. Frazier, T.P.; Burklew, C.E.; Zhang, B. Titanium Dioxide Nanoparticles Affect the Growth and Microrna Expression of Tobacco (Nicotiana tabacum). Funct. Integr. Genom. 2014, 14, 75-83. [CrossRef]

126. Kaveh, R.; Li, Y.-S.; Ranjbar, S.; Tehrani, R.; Brueck, C.; Van Aken, B. Changes in Arabidopsis thaliana Gene Expression in Response to Silver Nanoparticles and Silver Ions. Environ. Sci. Technol. 2013, 47, 10637-10644. [CrossRef] [PubMed]

127. Jin, Y.; Fan, X.; Li, X.; Zhang, Z.; Sun, L.; Fu, Z.; Lavoie, M.; Pan, X.; Qian, H. Distinct Physiological and Molecular Responses in Arabidopsis thaliana Exposed to Aluminum Oxide Nanoparticles and Ionic Aluminum. Environ. Pollut. 2017, $228,517-527$. [CrossRef] [PubMed]

128. Sanzari, I.; Leone, A.; Ambrosone, A. Nanotechnology in Plant Science: To Make a Long Story Short. Front. Bioeng. Biotechnol. 2019, 7, 120. [CrossRef] [PubMed]

129. An, J.; Hu, P.; Li, F.; Wu, H.; Shen, Y.; White, J.C.; Tian, X.; Li, Z.; Giraldo, J.P. Emerging Investigator Series: Molecular Mechanisms of Plant Salinity Stress Tolerance Improvement by Seed Priming with Cerium Oxide Nanoparticles. Environ. Sci. Nano 2020, 7 , 2214-2228. [CrossRef]

130. Večeřová, K.; Večeřa, Z.; Dočekal, B.; Oravec, M.; Pompeiano, A.; Tříska, J.; Urban, O. Changes of Primary and Secondary Metabolites In Barley Plants Exposed to CdO Nanoparticles. Environ. Pollut. 2016, 218, 207-218. [CrossRef]

131. Raigond, P.; Raigond, B.; Kaundal, B.; Singh, B.; Joshi, A.; Dutt, S. Effect of Zinc Nanoparticles on Antioxidative System of Potato Plants. J. Environ. Biol. 2017, 38, 435-439. [CrossRef]

132. Karimi, N.; Behbahani, M.; Dini, G.; Razmjou, A. Enhancing the Secondary Metabolite and Anticancer Activity of Echinacea Purpurea Callus Extracts by Treatment with Biosynthesized ZnO Nanoparticles. Adv. Nat. Sci. Nanosci. Nanotechnol. 2018, 9, 045009. [CrossRef]

133. Modarresi, M.; Chahardoli, A.; Karimi, N.; Chahardoli, S. Variations of Glaucine, Quercetin and Kaempferol Contents in Nigella arvensis Against $\mathrm{Al}_{2} \mathrm{O}_{3}, \mathrm{NiO}$, and $\mathrm{TiO}_{2}$ Nanoparticles. Heliyon 2020, 6, e04265. [CrossRef] [PubMed]

134. Sun, L.; Song, F.; Guo, J.; Zhu, X.; Liu, S.; Liu, F.; Li, X. Nano-ZnO-Induced Drought Tolerance is Associated with Melatonin Synthesis and Metabolism in Maize. Int. J. Mol. Sci. 2020, 21, 782. [CrossRef]

135. Zahedi, S.M.; Hosseini, M.S.; Daneshvar Hakimi Meybodi, N.; Peijnenburg, W. Mitigation of the Effect of Drought on Growth and Yield of Pomegranates by Foliar Spraying of Different Sizes of Selenium Nanoparticles. J. Sci. Food Agric. 2021. [CrossRef]

136. Gupta, B.; Huang, B. Mechanism of Salinity Tolerance in Plants: Physiological, Biochemical, and Molecular Characterization. Int. J. Genom. 2014, 2014, 1-18. [CrossRef]

137. Ji, H.; Pardo, J.M.; Batelli, G.; Van Oosten, M.J.; Bressan, R.A.; Li, X. The Salt Overly Sensitive (SOS) Pathway: Established and Emerging Roles. Mol. Plant 2013, 6, 275-286. [CrossRef] 
138. Ismail, A.; El-Sharkawy, I.; Sherif, S. Salt Stress Signals on Demand: Cellular Events in the Right Context. Int. J. Mol. Sci. 2020, 21, 3918. [CrossRef]

139. Ishitani, M.; Liu, J.; Halfter, U.; Kim, C.-S.; Shi, W.; Zhu, J.-K. SOS3 Function in Plant Salt Tolerance Requires N-Myristoylation and Calcium Binding. Plant Cell 2000, 12, 1667-1677. [CrossRef] [PubMed]

140. Martínez-Ballesta, M.C.; Zapata, L.; Chalbi, N.; Carvajal, M. Multiwalled carbon nanotubes enter broccoli cells enhancing growth and water uptake of plants exposed to salinity. J. Nanobiotechnol. 2016, 14, 1-14. [CrossRef] [PubMed]

141. Fleck, A.T.; Schulze, S.; Hinrichs, M.; Specht, A.; Waßmann, F.; Schreiber, L.; Schenk, M.K. Silicon Promotes Exodermal Casparian Band Formation in Si-Accumulating and Si-Excluding Species by Forming Phenol Complexes. PLoS ONE 2015, 10, e0138555. [CrossRef] [PubMed]

142. Shi, Y.; Wang, Y.; Flowers, T.J.; Gong, H. Silicon Decreases Chloride Transport in Rice (Oryza sativa L.) in Saline Conditions. J. Plant Physiol. 2013, 170, 847-853. [CrossRef]

143. Zhu, Y.-X.; Gong, H.-J.; Yin, J.-L. Role of Silicon in Mediating Salt Tolerance in Plants: A Review. Plants 2019, 8, 147. [CrossRef]

144. Dar, N.A.; Amin, I.; Wani, W.; Wani, S.A.; Shikari, A.B.; Wani, S.H.; Masoodi, K.Z. Abscisic Acid: A Key Regulator of Abiotic Stress Tolerance in Plants. Plant Gene 2017, 11, 106-111. [CrossRef]

145. Sah, S.K.; Reddy, K.R.; Li, J. Abscisic Acid and Abiotic Stress Tolerance in Crop Plants. Front. Plant Sci. 2016, 7, 571. [CrossRef] [PubMed]

146. Sun, D.; Hussain, H.I.; Yi, Z.; Rookes, J.E.; Kong, L.; Cahill, D.M. Delivery of Abscisic Acid to Plants Using Glutathione Responsive Mesoporous Silica Nanoparticles. J. Nanosci. Nanotechnol. 2018, 18, 1615-1625. [CrossRef] [PubMed]

147. Khan, I.; Raza, M.A.; Awan, S.A.; Shah, G.A.; Rizwan, M.; Ali, B.; Tariq, R.; Hassan, M.J.; Alyemeni, M.N.; Brestic, M.; et al. Amelioration of Salt Induced Toxicity in Pearl Millet by Seed Priming with Silver Nanoparticles (AgNPs): The Oxidative Damage, Antioxidant Enzymes and Ions Uptake are Major Determinants of Salt Tolerant Capacity. Plant Physiol. Biochem. 2020, 156, 221-232. [CrossRef]

148. Jahani, M.; Khavari-Nejad, R.A.; Mahmoodzadeh, H.; Saadatmand, S. Effects of Cobalt Oxide Nanoparticles $\left(\mathrm{CO}_{3} \mathrm{O}_{4} \mathrm{NPs}\right)$ on Ion Leakage, Total Phenol, Antioxidant Enzymes Activities and Cobalt Accumulation in Brassica napus L. Not. Bot. Hortic. Agrobot. Cluj-Napoca 2020, 48, 1260-1275. [CrossRef]

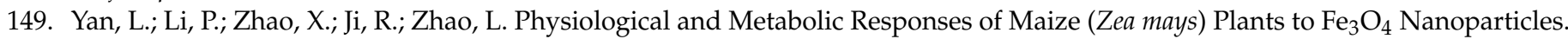
Sci. Total Environ. 2020, 718, 137400. [CrossRef]

150. Sofy, A.; Sofy, M.; Hmed, A.; Dawoud, R.; Alnaggar, A.; Soliman, A.; El-Dougdoug, N. Ameliorating the Adverse Effects of Tomato mosaic tobamovirus Infecting Tomato Plants in Egypt by Boosting Immunity in Tomato Plants Using Zinc Oxide Nanoparticles. Molecules 2021, 26, 1337. [CrossRef] [PubMed]

151. Chahardoli, A.; Karimi, N.; Ma, X.; Qalekhani, F. Effects of Engineered Aluminum and Nickel Oxide Nanoparticles on the Growth and Antioxidant Defense Systems of Nigella arvensis L. Sci. Rep. 2020, 10, 1-11. [CrossRef]

152. Pelegrino, M.T.; Pieretti, J.C.; Lange, C.N.; Kohatsu, M.Y.; Freire, B.M.; Batista, B.L.; Fincheira, P.; Tortella, G.R.; Rubilar, O.; Seabra, A.B.; et al. Foliar Spray Application of CuO Nanoparticles (NPs) and S -Nitrosoglutathione Enhances Productivity, Physiological and Biochemical Parameters of Lettuce Plants. J. Chem. Technol. Biotechnol. 2021. [CrossRef]

153. Sohail; Kamran, K.; Kemmerling, B.; Shutaywi, M.; Mashwani, Z.U.R. Nano Zinc Elicited Biochemical Characterization, Nutritional Assessment, Antioxidant Enzymes and Fatty Acid Profiling of Rapeseed. PLoS ONE 2020, 15, e0241568. [CrossRef]

154. Pavani, K.V.; Beulah, M.; Poojitha, G.U.S.; Kantabathini, V.P.; Mallula, B.; Udayar, S.P.G. The Effect of Zinc Oxide Nanoparticles (ZnO NPs) on Vigna mungo L. Seedling Growth and Antioxidant Activity. Nanosci. Nanotechnol. Asia 2020, 10, 117-122. [CrossRef]

155. Marchiol, L.; Iafisco, M.; Fellet, G.; Adamiano, A. Nanotechnology Support the Next Agricultural Revolution: Perspectives to Enhancement of Nutrient Use Efficiency. In Advances in Agronomy; Academic Press Sparks: Amsterdam, The Netherlands, 2020; Volume 161, pp. 27-116. 